\title{
Hydroxylamine Nitrate Decomposition under Non-radiological Conditions
}

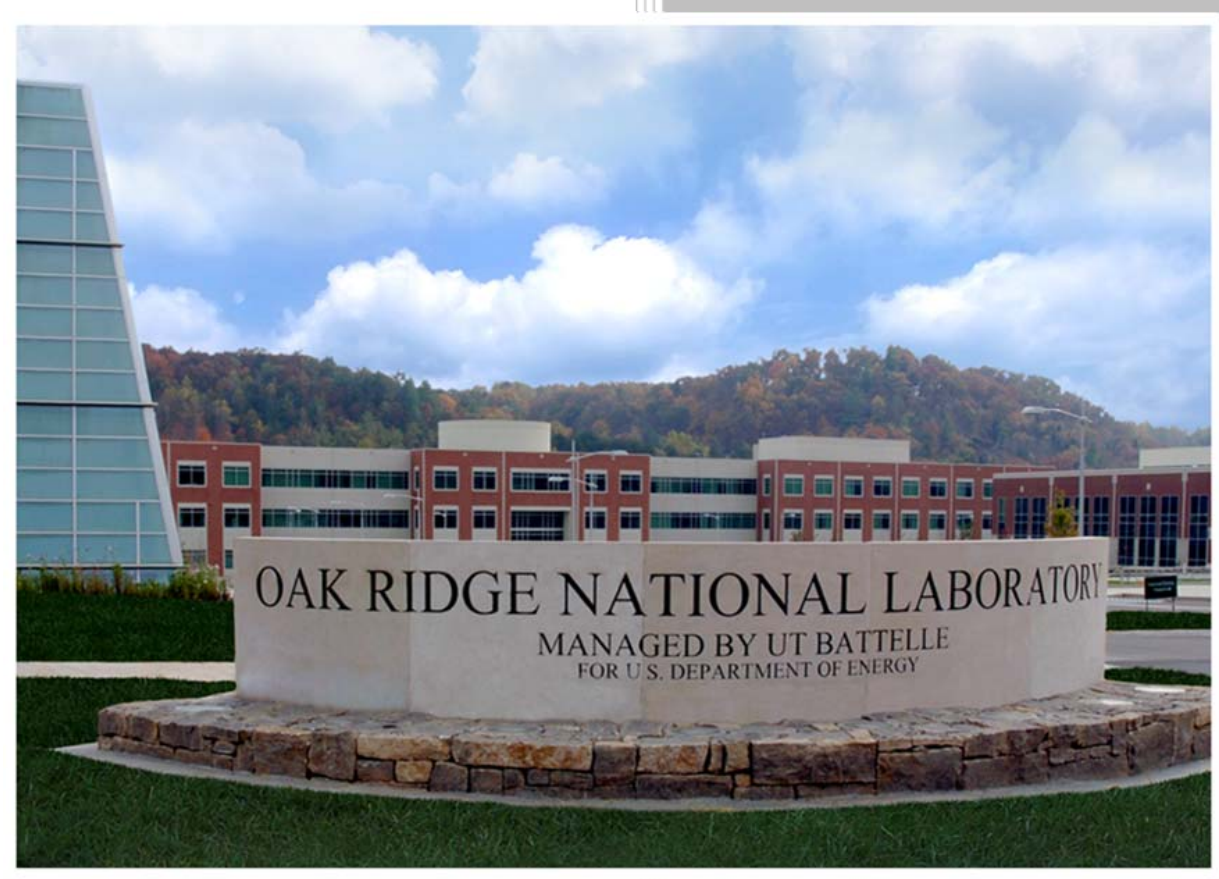

Approved for public release; distribution is unlimited.
J. McFarlane

L.H. Delmau

D.W. DePaoli

C.H. Mattus

C.E. Phelps

B.D. Roach

July 2015 


\title{
DOCUMENT AVAILABILITY
}

Reports produced after January 1, 1996, are generally available free via US Department of Energy (DOE) SciTech Connect.

Website http://www.osti.gov/scitech/

Reports produced before January 1, 1996, may be purchased by members of the public from the following source:

\author{
National Technical Information Service \\ 5285 Port Royal Road \\ Springfield, VA 22161 \\ Telephone 703-605-6000 (1-800-553-6847) \\ TDD 703-487-4639 \\ Fax 703-605-6900 \\ E-mail info@ntis.gov \\ Website http://www.ntis.gov/help/ordermethods.aspx
}

Reports are available to DOE employees, DOE contractors, Energy Technology Data Exchange representatives, and International Nuclear Information System representatives from the following source:

Office of Scientific and Technical Information

PO Box 62

Oak Ridge, TN 37831

Telephone 865-576-8401

Fax 865-576-5728

E-mail reports@osti.gov

Website http://www.osti.gov/contact.html

This report was prepared as an account of work sponsored by an agency of the United States Government. Neither the United States Government nor any agency thereof, nor any of their employees, makes any warranty, express or implied, or assumes any legal liability or responsibility for the accuracy, completeness, or usefulness of any information, apparatus, product, or process disclosed, or represents that its use would not infringe privately owned rights. Reference herein to any specific commercial product, process, or service by trade name, trademark, manufacturer, or otherwise, does not necessarily constitute or imply its endorsement, recommendation, or favoring by the United States Government or any agency thereof. The views and opinions of authors expressed herein do not necessarily state or reflect those of the United States Government or any agency thereof. 
Energy and Transportation Science Division

\title{
HYDROXYLAMINE NITRATE DECOMPOSITION UNDER NON-RADIOLOGICAL CONDITIONS
}

\author{
J. McFarlane \\ L.H. Delmau \\ D.W. DePaoli \\ C.H. Mattus \\ C.E. Phelps \\ B.D. Roach
}

July 2015:

Prepared by OAK RIDGE NATIONAL LABORATORY

Oak Ridge, TN 37831-6181

managed by

UT-BATTELLE, LLC

for the

US DEPARTMENT OF ENERGY

under contract DE-AC05-00OR22725 



\section{CONTENTS}

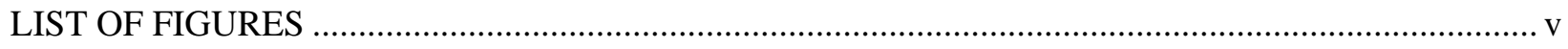

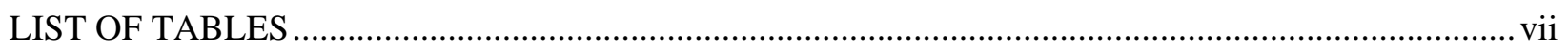

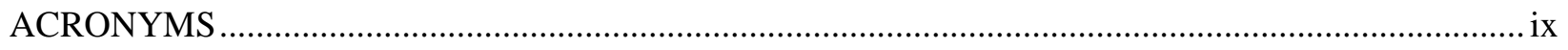

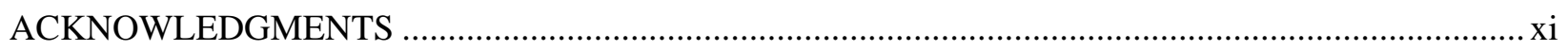

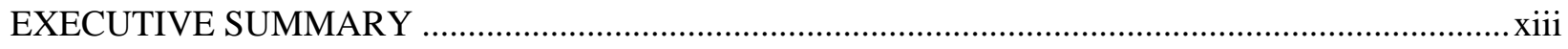

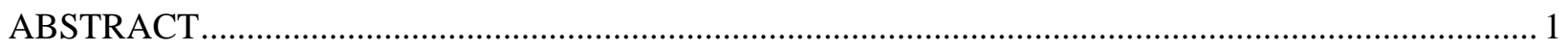

1. REVIEW OF THE USE OF HYDROXYLAMINE NITRATE IN THE REDUCTION OF

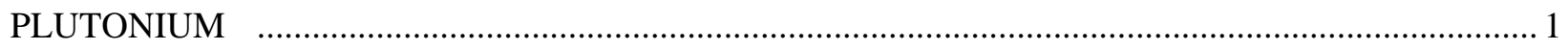

1.1 METHODS FOR SAFE REMOVAL OR DISPOSAL …............................................. 7

1.2 ALTERNATIVE REDUCING AGENTS FOR PLUTONIUM ….................................. 8

1.3 SAFE HANDLING OF HAN DURING EXPERIMENTAL STUDIES .......................... 9

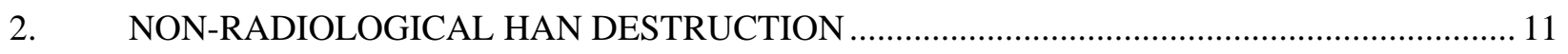

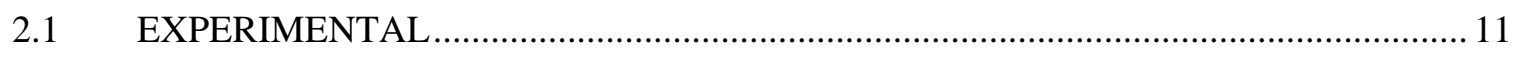

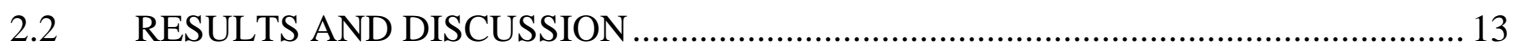

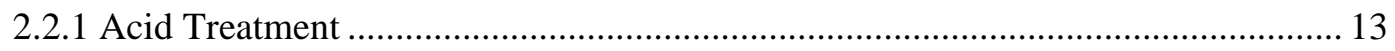

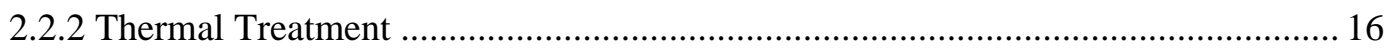

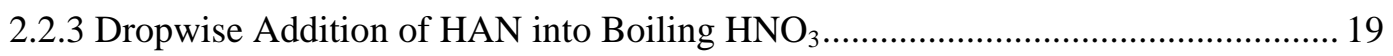

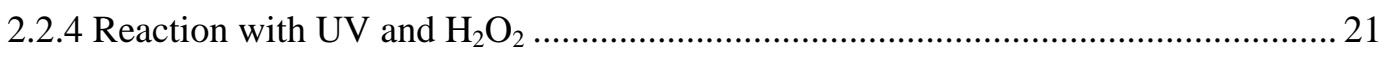

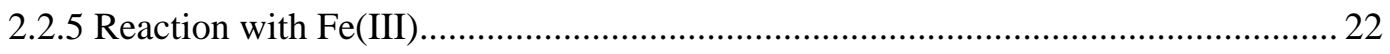

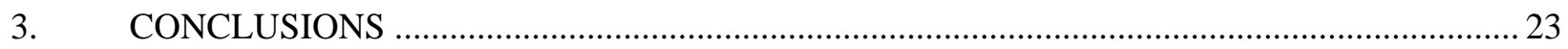

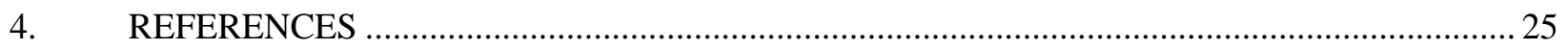

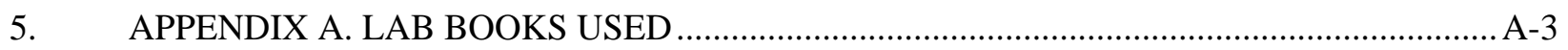





\section{LIST OF FIGURES}

Figure 1. Instability index (Equation 1 ) as a function of temperature $\left({ }^{\circ} \mathrm{C}\right)$.

Figure 2. Reagent temperature at which the SRNL instability index is greater than the critical value as a function of $\mathrm{HNO}_{3}(\mathrm{~mol} / \mathrm{L})$.

Figure 3. Monitoring of HAN through the use of $\mathrm{HNO}_{2} \mathrm{UV}$ spectroscopy, showing a reaction in the Cary spectrophotometer cuvette.

Figure 4. Calibration of the measurement of nitrous acid in the Cary UV spectrophotometer, absorbance versus nitrite ion concentration.

Figure 5. Absorbance of $\mathrm{HNO}_{2}$ as a function of time in $17 \mathrm{mM} \mathrm{HNO}_{3}$............................................. 14

Figure 6. Concentration of $\mathrm{HNO}_{2}$ versus time (min) showing residual HAN in nitric acid solution .......... 15

Figure 7. Concentration of HAN as a function of time (min) in the presence of heated $\mathrm{HNO}_{3} \ldots \ldots \ldots \ldots \ldots . . . . . .16$

Figure 8. HAN (mol/L) after contact with $\mathrm{HNO}_{3}$ for up to $60 \mathrm{~min}$..................................................... 18

Figure 9. Concentration of HAN (mol/L) as a function of reaction temperature with samples taken

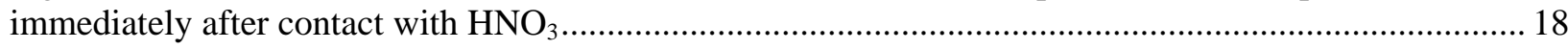

Figure 10. HAN (mol/L) after reacting with $3 \mathrm{M} \mathrm{HNO}_{3}$ as a function of temperature.............................. 19

Figure 11. HAN concentrations (mM) as a function of time (min) as calculated from the amount added to boiling $2 \mathrm{M} \mathrm{HNO}_{3}$ and the concentration measured through $\mathrm{HNO}_{2}$ spectrophotometry ........................... 20

Figure 12. HAN concentration (mol/L) as a function of time (min) under $\mathrm{UV}$ and $\mathrm{H}_{2} \mathrm{O}_{2} \ldots \ldots \ldots \ldots \ldots \ldots \ldots . . . . . . . . . .21$

Figure 13. Apparent [HAN] (mol/L) as a function of time, from monitoring of the $\mathrm{HNO}_{2}$ absorption at

$371 \mathrm{~nm}$ 



\section{LIST OF TABLES}

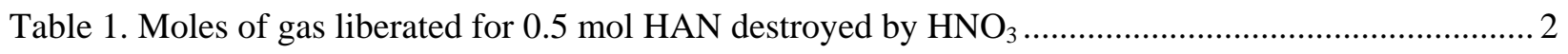

Table 2. Reaction parameters important in rate control................................................................... 5

Table 3. Thermophysical properties of HAN solutions ................................................................... 7

Table 4. Suggested methods to achieve HAN destruction ...................................................................... 11

Table 5. Reduction of $\mathrm{HAN}$ in $\mathrm{HNO}_{3}$ as a function of $[\mathrm{HAN}]$ and $\left[\mathrm{HNO}_{3}\right]$ at room temperature ............. 15

Table 6. HAN Concentration (M) in $\mathrm{HAN}+\mathrm{HNO}_{3}$ mixtures as a function of temperature ....................... 17

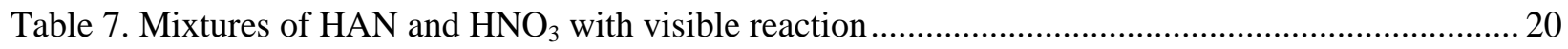





\section{ACRONYMS}

CFD computational fluid dynamics

DI deionized water

DTA differential thermal analysis

HA hydroxylamine

HAN hydroxylamine nitrate

HPLC high pressure liquid chromatography

HSA sulfamic acid

IC ion chromatography

IR infrared

ORNL Oak Ridge National Laboratory

QCL quantum cascade laser

PUREX plutonium uranium redox extraction

REDC Radiochemical Engineering Development Center

SADT self-accelerating decomposition temperature

SRNL Savannah River National Laboratory

TBP tributylphosphate

TGA thermogravimetric analysis

UV ultraviolet 



\section{ACKNOWLEDGMENTS}

This work was supported by the Pu-238 Production Project. The manuscript was authored by UT-Battelle, under Contract DEAC05-00OR22725 with the US Department of Energy. 



\section{EXECUTIVE SUMMARY}

Hydroxylamine nitrate (HAN) is used to reduce $\mathrm{Pu}(\mathrm{IV})$ to $\mathrm{Pu}(\mathrm{III})$ in the separation of plutonium from uranium. HAN becomes unstable under certain conditions and has been known to explode. Hence, it is necessary to deactivate HAN once the solution has been used in a process. This report reviews what is known about the chemistry of HAN and various methods to achieve a safe decomposition. Experiments have demonstrated a number of non-radiolytic ways to safely decompose HAN, including heating in $\mathrm{HNO}_{3}$, photolytic oxidation in the presence of $\mathrm{H}_{2} \mathrm{O}_{2}$, and the addition of a metal such as Fe(III) that will oxidize the HAN. Safe handling of HAN and precursor solutions should include the following precautions.

- Store HAN in the original and sealed manufacturer's shipping container. When HAN is removed, reseal the container to prevent concentration through evaporation.

- Only make up required solution volumes. $\mathrm{HNO}_{2}$, which reacts with $\mathrm{HAN}$, is always present in concentrated $\mathrm{HNO}_{3}$.

- To minimize the accumulation of $\mathrm{HNO}_{2}$, protect solutions of $\mathrm{NaNO}_{2}$ and $\mathrm{HNO}_{3}$ from strong room light, and sparge solutions of $\mathrm{HNO}_{3}$ to remove NOx initially. Monitor $\mathrm{HNO}_{2}$ concentration.

- Use glass or Teflon sheathed reaction vessels and thermocouples to reduce the possibility of catalysis. Use plastic containers and disposable plastic pipettes for transferring hydroxylamine solutions. Even a small surface area of a metal thermocouple will accelerate the HA decomposition reaction and reduce the threshold temperature for reaction. Silica coating is not effective at passivating the surface.

- Control heating conditions. Provide cooling if necessary.

- Do not directly add concentrated acid to hydroxylamine (HA).

- If the apparatus is to be shutdown, drain the chemicals from the system and flush the apparatus with water until neutral $\mathrm{pH}$ is achieved. Refill the apparatus with water for storage.

- Ensure that pressure relief is available on reaction vessels or that they are open to the atmosphere.

- Monitor stored solutions of HAN and HA for breakdown products and crystals.

- Dispose of chemicals expeditiously and following predetermined protocols.

Safe operation when working with $\mathrm{HAN}$ appears to be with acidities less than $2 \mathrm{M} \mathrm{HNO}_{3}$ at temperatures up to $60^{\circ} \mathrm{C}$.

If immediate destruction is desired, this can be achieved in a controlled manner by heating of the HAN solution to $75^{\circ} \mathrm{C}$ mixed with concentrations of $\mathrm{HNO}_{3}$ of at least $3 \mathrm{M}$. 



\begin{abstract}
Hydroxylamine nitrate (HAN) is used to reduce $\mathrm{Pu}(\mathrm{IV})$ to $\mathrm{Pu}(\mathrm{III})$ in the separation of plutonium from uranium. HAN becomes unstable under certain conditions and has been known to explode, causing injury to humans including death. ${ }^{[1-3]}$ Hence, it is necessary to deactivate HAN once the reduction of plutonium is finished. This report reviews what is known about the chemistry of HAN and various methods to achieve a safe decomposition. However, there are areas where more information is needed to make a decision about the handling of HAN in reprocessing of nuclear fuel. Experiments have demonstrated a number of non-radiolytic ways to safely decompose HAN, including heating in $\mathrm{HNO}_{3}$, photolytic oxidation in the presence of $\mathrm{H}_{2} \mathrm{O}_{2}$, and the addition of a metal such as $\mathrm{Fe}(\mathrm{III})$ that will oxidize the HAN. Safe operation when working with HAN appears to be with acidities less than $2 \mathrm{M} \mathrm{HNO}_{3}$ at temperatures up to $60^{\circ} \mathrm{C}$. If immediate destruction is desired, this can be achieved by heating of the $\mathrm{HAN}$ solution to $75^{\circ} \mathrm{C}$ mixed with concentrations of $\mathrm{HNO}_{3}$ of at least $3 \mathrm{M}$.
\end{abstract}

\title{
1. REVIEW OF THE USE OF HYDROXYLAMINE NITRATE IN THE REDUCTION OF PLUTONIUM
}

The chemistry of the reactions involving hydroxylamine nitrate relevant to plutonium oxidation have been reviewed by Harlow and coworkers ${ }^{[4]}$. Plutonium and uranium are both present as oxides in irradiated nuclear fuel, which are separated using the plutonium uranium redox extraction (PUREX) process, involving dissolution in $6 \mathrm{M}$ nitric acid at $40-60^{\circ} \mathrm{C}^{[5]}$. Complexes of uranium and plutonium are then extracted into an organic/tributyl phosphate phase. The organic is then contacted with nitric acid in which a reducing agent is dissolved. In nitric acid, hydroxylamine, HA, is present as its conjugate acid, $\mathrm{NH}_{3} \mathrm{OH}^{+}$, as its $\mathrm{pKa}$ is 5.96. The protonated hydroxylamine will associate with the nitrate ion, thus forming a hydroxylamine nitrate ion pair, HAN.

HAN is used to reduce plutonium allow it to be separated from uranium in mixer-settlers ${ }^{[6]}$. The oxidation state of uranium does not change, so the uranium will remain in the organic phase and the plutonium will partition and be reduced in the aqueous phase. The overall steps for the reduction of plutonium are given in (1) and (2) and show the evolution of $\mathrm{N}_{2} \mathrm{O}$ and $\mathrm{N}_{2}$ during the process. The mole ratio of $\mathrm{HA}$ to $\mathrm{Pu}^{4+}$ in the reduction is 1.3 to 1.6. It is important to prevent the re-oxidation of plutonium to minimize the re-extraction back into the organic phase ${ }^{[7]}$. $\mathrm{HNO}_{2}$, formed in thermal equilibrium with $\mathrm{HNO}_{3}$ and also from radiolysis, can reoxidize plutonium and also decompose residual HAN and so becomes an important intermediate species in solution.

$$
\begin{aligned}
& 2 \mathrm{NH}_{3} \mathrm{OH}^{+}+2 \mathrm{Pu}^{4+} \rightarrow 2 \mathrm{Pu}^{3+}+\mathrm{N}_{2} \mathrm{O}(\mathrm{g})+\mathrm{H}_{2} \mathrm{O}+6 \mathrm{H}^{+} \\
& 2 \mathrm{NH}_{3} \mathrm{OH}^{+}+2 \mathrm{Pu}^{4+} \rightarrow 2 \mathrm{Pu}^{3+}+\mathrm{N}_{2}(\mathrm{~g})+2 \mathrm{H}_{2} \mathrm{O}+4 \mathrm{H}^{+}
\end{aligned}
$$

The first step in the decomposition of HAN is the formation of HA. Hydroxylamine is classified as a selfreactive substance ${ }^{[8]}$. A thermal run away reaction can occur, generating nitrous acid in solution, a strongly exothermic process. The autocatalytic reaction scheme that takes place in nitric acid solution follows Reactions (3-6). The overall process is given in Reaction (7), showing the conversion of nitric to nitrous acid ${ }^{[9]}$.

$$
\begin{gathered}
\mathrm{H}^{+}+\mathrm{HNO}_{2}+\mathrm{NO}_{3}^{-} \leftrightarrow \mathrm{N}_{2} \mathrm{O}_{4}+\mathrm{H}_{2} \mathrm{O} \\
\mathrm{N}_{2} \mathrm{O}_{4}+\mathrm{NH}_{2} \mathrm{OH} \rightarrow \mathrm{HNO}+\mathrm{N}_{2} \mathrm{O}_{3}+\mathrm{H}_{2} \mathrm{O}
\end{gathered}
$$




$$
\begin{gathered}
\mathrm{N}_{2} \mathrm{O}_{4}+\mathrm{HNO} \rightarrow \mathrm{HNO}_{2}+\mathrm{N}_{2} \mathrm{O}_{3} \\
\mathrm{~N}_{2} \mathrm{O}_{3}+\mathrm{H}_{2} \mathrm{O} \rightarrow 2 \mathrm{HNO}_{2} \\
2 \mathrm{HNO}_{3}+\mathrm{NH}_{2} \mathrm{OH} \rightarrow 2 \mathrm{HNO}_{2}+\mathrm{H}_{2} \mathrm{O}
\end{gathered}
$$

Reaction (7) follows second order kinetics at acid concentrations from 3-8M, but the rate constant drops to zero at lower acid concentrations.

$$
\mathrm{HNO}_{2}+\mathrm{NH}_{3} \mathrm{OH}^{+} \rightarrow \mathrm{N}_{2} \mathrm{O}+2 \mathrm{H}_{2} \mathrm{O}+\mathrm{H}^{+}
$$

The decomposition of HAN, Reaction (8), competes with the autocatalysis. This reaction dominates at low temperatures, low $\mathrm{HNO}_{3}$ and low ionic strength $\left(<2 \mathrm{M}\right.$ ionic strength or concentration of $\mathrm{HNO}_{3}$ and low iron concentrations), because Reaction (3) becomes rate limiting. However, as Reaction (8) progresses consuming $\mathrm{NH}_{3} \mathrm{OH}^{+}$; the amount of $\mathrm{HNO}_{2}$ can increase, thus causing conditions where autocatalysis can dominate. The reaction (8) follows second order kinetics ${ }^{[10]}$ and rate constants for all of these reactions are given by Gowland and Stedman ${ }^{[9]}$, with the caveat that their mechanism applies to HA concentrations less than $0.01 \mathrm{M}$. At very high concentrations of $\mathrm{HNO}_{3}$, the acid is not completely dissociated, and important species in the reaction mechanism may include more complicated adducts with $\mathrm{HNO}_{3}$. The rate of the autocatalysis is also highly dependent on the overall ionic strength of the solution.

The thermochemistry of the decomposition of $50 \mathrm{wt} . \% \mathrm{HA} / \mathrm{H}_{2} \mathrm{O}$ has been measured in an adiabatic calorimeter and results indicated that the heat of reaction was $-124 \mathrm{~kJ} / \mathrm{mol}{ }^{[11]}$. Decomposition products in a system studied by Liu and coworkers were found to include $\mathrm{NH}_{3}(\mathrm{~g}), \mathrm{N}_{2}(\mathrm{~g}), \mathrm{N}_{2} \mathrm{O}(\mathrm{g}), \mathrm{NO}(\mathrm{g}), \mathrm{H}_{2} \mathrm{O}(\mathrm{g})$ and $\mathrm{H}_{2}$ (g), with a ratio of $\mathrm{N}_{2}$ to $\mathrm{N}_{2} \mathrm{O}$ of 2.9 under autocatalytic conditions. ${ }^{[12]}$ The reaction rate was not affected by addition of $\mathrm{O}_{2}$ into the system. The mechanism of decomposition of HA was thought to go through an ammonia related compound ${ }^{[12,13]}$, and $\mathrm{N}_{2}$ formed from the recombination of $\mathrm{NH}_{2} \mathrm{O} \cdot$ radicals ${ }^{[14]}$. Gas release during heating of HA has also been studied in an isoperibolic apparatus ${ }^{[15]}$. Using the reaction mechanism proposed by Barney and Duval, ${ }^{[16]}$ and equation (9) for low concentrations of acid, the moles of gas liberated for 0.5 mol HAN destroyed is given in Table 1 . Both the maximum value of $x$ and the moles of gas released vary greatly with the concentration of nitric acid.

$$
\mathrm{HAN}+0.5(\mathrm{x}+1) \mathrm{HNO}_{3} \rightarrow \mathrm{xHNO}_{2}+0.25(3-\mathrm{x}) \mathrm{N}_{2} \mathrm{O}+\mathrm{H}^{+}+(1.75-0.25 \mathrm{x}) \mathrm{H}_{2} \mathrm{O}
$$

Table 1. Moles of gas liberated for 0.5 mol HAN destroyed by $\mathrm{HNO}_{3}$

\begin{tabular}{ccc}
\hline $\mathrm{HNO}_{3}(\mathrm{M})$ & moles gas & maximum x (Equation 1) \\
\hline 0.5 & $0.75 \mathrm{~N}_{2} \mathrm{O}$ & 0 \\
1 & $0.5 \mathrm{~N}_{2} \mathrm{O}$ & 1 \\
2 & $3 \mathrm{NO}_{2}$ & 3 \\
3 & $3 \mathrm{NO}_{2}$ & not applicable \\
4 & $3 \mathrm{NO}_{2}$ & not applicable \\
5 & $3 \mathrm{NO}_{2}$ & not applicable \\
8 & $3 \mathrm{NO}_{2}$ & not applicable \\
\hline
\end{tabular}

In the experiments by Liu and colleagues, ${ }^{[12]}$ HAN decomposition (18 wt.\%) had a different time profile than HA, with no heat releases observed in a glass vessel up to $160^{\circ} \mathrm{C}$. In a titanium vessel, a strong exothermic reaction occurred after an 800 minute induction period, causing the pressure to rapidly increase to 20 bar in the closed vessel. However, their proposed mechanism of $\mathrm{NH}_{3}(\mathrm{~g})$ release is unlikely to apply to HAN decomposition in strong nitric acid. The reaction mechanism for the decomposition of 
HAN under acidic conditions has been studied in much detail, but there are aspects that are still being debated. For instance, Wei and coworkers ${ }^{[14]}$ report that the autocatalytic reaction to produce $\mathrm{N}_{2} \mathrm{O}$ involves the recombination of $\mathrm{HNO}$, an intermediate not mentioned in the scheme from Gowland and Stedman ${ }^{[9]}$ above.

Iron reacts like plutonium in Reaction (1), but also generates $\mathrm{HNO}_{2}$, Reaction (9), giving an overall Reaction (10) when present. Even low concentrations of iron have been found to lower the selfaccelerating decomposition temperature (SADT), for instance SADT for $50 \mathrm{wt} \% \mathrm{HA}$ in water goes from $80^{\circ} \mathrm{C}$ with $0.1-1.0 \mathrm{ppm} \mathrm{Fe}^{3+}$ to $55^{\circ} \mathrm{C}$ with $5.2 \mathrm{ppm} \mathrm{Fe}^{3+}{ }^{[17]}$. For higher concentrations of $\mathrm{HA}$ in water (85 wt.\%), the required concentration of $\mathrm{Fe}^{3+}$ for autocatalytic onset is even lower ${ }^{[18]}$. Accelerated reactions have been observed with HA heated in contact with stainless steel and titanium ${ }^{[19]}$.

$$
\begin{gathered}
2 \mathrm{Fe}^{2+}+\mathrm{HNO}_{3}+2 \mathrm{H}+\rightarrow 2 \mathrm{Fe}^{3+}+\mathrm{HNO}_{2}+\mathrm{H}_{2} \mathrm{O} \\
2 \mathrm{HAN} \rightarrow \mathrm{N}_{2} \mathrm{O}(\mathrm{g})+3 \mathrm{H}_{2} \mathrm{O}+2 \mathrm{HNO}_{2}
\end{gathered}
$$

Although iron accelerates the decomposition of HAN, it does not change the heat of reaction or the amount of gaseous products. Hence, the reaction mechanism is thought to be unchanged with the presence of $\mathrm{Fe}^{3+}{ }^{200}$. Stabilizers for HA storage include organics that can complex metals ions in the aqueous phase, such as copper ions, $\mathrm{Co}^{2+}, \mathrm{Fe}^{2+}$, manganese and zinc. Potassium ethyl zanthate, 8-hydroxyquinoline, dithoizone, and polyethyleneamines have been suggested as reaction inhibitors ${ }^{[21]}$.

Non-metallic impurities have also been studied as to their effect on the decomposition of HA ${ }^{[14]}$. Through the addition of $\mathrm{KOH}, \mathrm{HCl}$, and $\mathrm{KCl}$, and by monitoring the effect on onset temperature, rate of temperature excursion, and maximum pressure, Wei and coworkers surmised that $\mathrm{OH}^{-}$, and $\mathrm{H}^{+}$both participate in the decomposition of HA. Conversely, $\mathrm{K}^{+}$did not affect the reaction rate, but $\mathrm{Cl}^{-}$may itself be oxidized by HA, increasing the heat release from the reactions. Liu summarizes many of the proposed decomposition mechanisms in his thesis ${ }^{[20]}$. In addition to the addition of contaminants, various formulations of HA have been investigated, including the hydrochloride, the sulfate, and the orthosulfonic acid forms, with the sulfate, in particular, becoming extremely unstable at temperatures less than $50^{\circ} \mathrm{C}^{[22]}$.

Hence, the chemistry of HAN decomposition is complex and there are many factors that affect the reaction mechanism and the products. These are listed in Table 2. The effects on HAN stability have been summarized by Savannah River National Laboratory (SRNL) into an "instability” index, I, Equation (1)

$$
I=\left(1+\left[\mathrm{HNO}_{3}\right]\right)^{\left(1+\log \left(\frac{\left[\mathrm{HNO}_{3}\right]}{[\mathrm{HAN}]}\right)\right)}+\left(1+\left[\mathrm{HNO}_{3}\right]\right)^{(1+\log (1+100[\mathrm{Fe}]))}
$$

where $\left[\mathrm{HNO}_{3}\right]$ is nitric acid molarity, $\left[\mathrm{HNO}_{3} / \mathrm{HAN}\right]$ is the molar ratio of nitric acid to $\mathrm{HAN}$, and $[\mathrm{Fe}]$ is the iron molarity. Higher values of $I$ are inversely correlated with temperatures at which a solution is stable. For instance, the instability index cut off ranges from 0 at $75^{\circ} \mathrm{C}$ (all concentrations being reactive) to 80 at $0^{\circ} \mathrm{C}$, with higher values corresponding to unstable solutions ${ }^{[4]}$. Figure 1 shows the calculated critical index as a function of temperature, so systems with $I$ to the left of the line will be unstable and systems to the right of the line will be stable over time. 


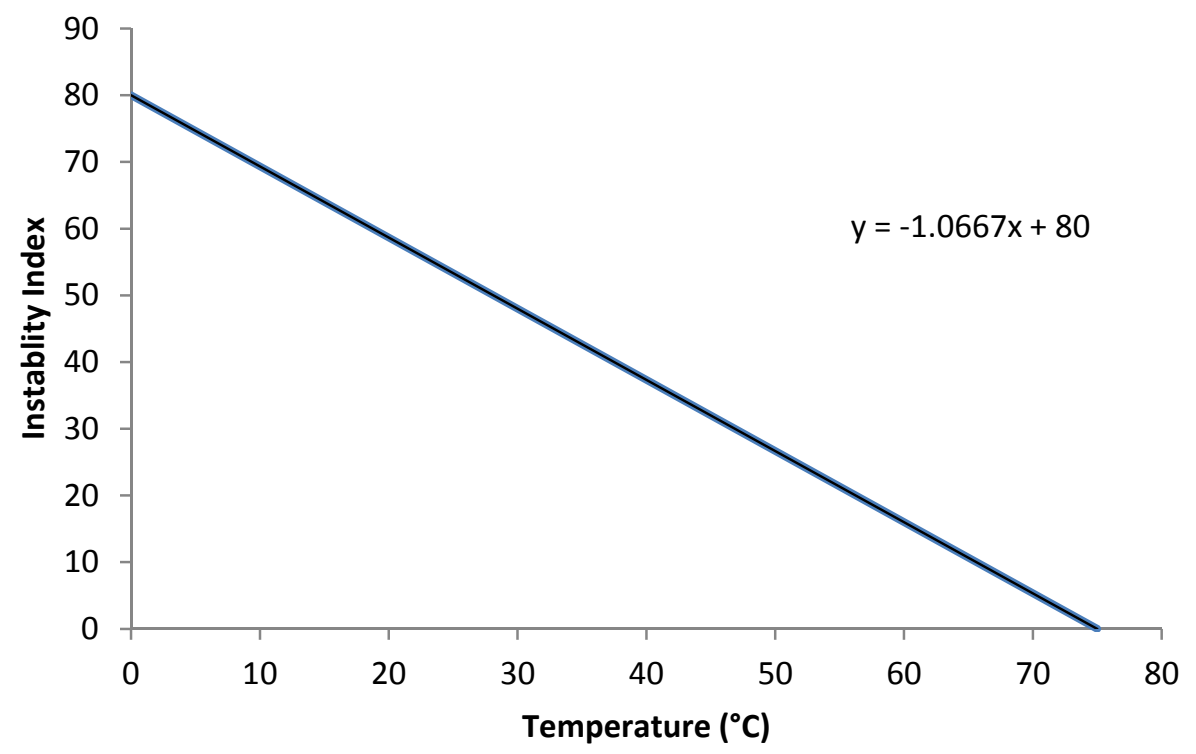

Figure 1. Instability index (Equation 1) as a function of temperature $\left({ }^{\circ} \mathbf{C}\right) . \mathrm{HAN} / \mathrm{HNO}_{3}$ systems to the right of the line will be unstable and autocatalytic and systems to the left of the line should be stable.

Calculation of the instability index can be turned around to give the temperature at which the reagents will exceed the critical value for a particular set of conditions. Figure 2 shows results of this calculation for $\mathrm{HNO}_{3}$ concentrations from 0.5 to $3 \mathrm{M}$, each line corresponding to a different concentration of HAN, from 0.1 to $1.5 \mathrm{M}$. Although a helpful analysis at low acid concentrations, the instability index model shows anomalies at low HAN concentration, $<0.5 \mathrm{M}$, and is not conservative at $\mathrm{HNO}_{3}$ concentrations above 3M.

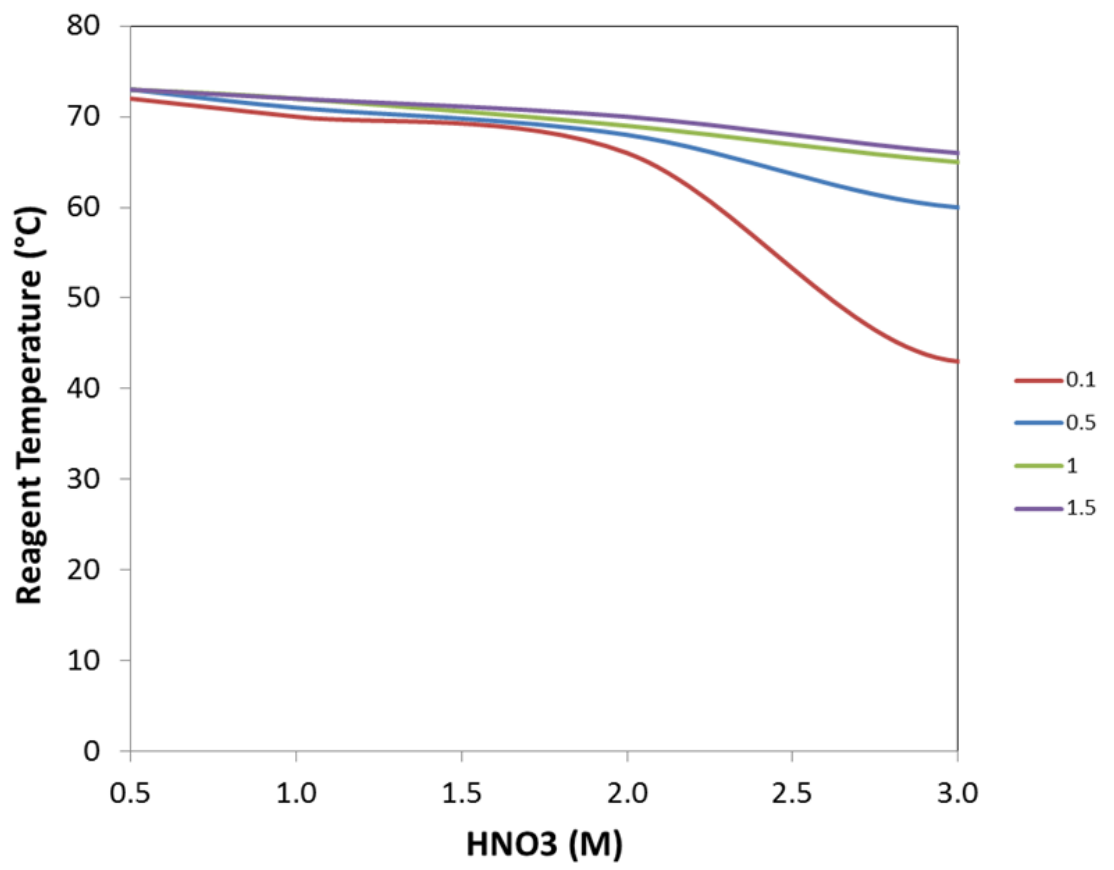

Figure 2. Reagent temperature at which the SRNL instability index is greater than the critical value as a function of $\mathrm{HNO}_{3}(\mathrm{~mol} / \mathrm{L})$. The calculation was done for HAN concentrations from 0.1 to $1.5 \mathrm{M}$. 
Table 2. Reaction parameters important in rate control

\begin{tabular}{|c|c|c|}
\hline Parameter & Why important & How to mitigate \\
\hline Concentration & $\begin{array}{l}\text { Through evaporation, improper } \\
\text { flushing of system before acid } \\
\text { addition } \\
\text { High concentration can get } \\
\text { precipitates of HA - explosive }\end{array}$ & $\begin{array}{l}\text { No explosion possible under dilute } \\
\text { conditions }(\sim 0.1 \mathrm{M}) \text { so prevents } \\
\text { inadvertent concentration or make } \\
\text { up of concentrated solution. Keep } \\
\text { HAN solutions ( }<70 \text { wt } \%)\end{array}$ \\
\hline Acid/HAN ratio & $\begin{array}{l}\text { More acid promotes autocatalysis } \\
\text { reactions beyond the } \mathrm{NH}_{2} \mathrm{OH} \\
+\mathrm{HNO}_{2} \text { reaction }\end{array}$ & $\begin{array}{l}\text { Keep acid/HAN ratio at }<2: 1 \text {, and } \\
\mathrm{HAN}<2 \mathrm{M} \text {. Onset temperature } \\
\text { decreased from } 171 \text { to } 147^{\circ} \mathrm{C} \text { when } \\
{\left[\mathrm{HNO}_{3}\right] \text { increased to } 1.38 \mathrm{M}^{[20]}}\end{array}$ \\
\hline Temperature & $\begin{array}{l}\text { Promotes evaporation to } \\
\text { concentrated solutions } \\
\text { Accelerates autocatalytic reactions }\end{array}$ & $\begin{array}{l}\text { Miminize exposure to external heat } \\
\text { sources, especially over extended } \\
\text { periods of time } \\
\text { Manage heat of mixing } \\
\text { Maintain temperature }<<40^{\circ} \mathrm{C}\end{array}$ \\
\hline Catalyst & $\begin{array}{l}\text { Fe impurity from stainless steel or } \\
\text { carbon steel } \\
\text { Some catalysis with } \mathrm{Cu} \text {. None with } \\
\mathrm{Ni}, \mathrm{Cr}, \mathrm{Mn}\end{array}$ & $\begin{array}{l}\text { No standing liquids or long term } \\
\text { storage } \\
\text { Use stainless steel, perhaps } \\
\text { passivated with } \mathrm{HNO}_{3} \\
\text { Monitoring to keep } \mathrm{Fe}^{+3}<1 \text { ppm. }\end{array}$ \\
\hline Pressure & Gases released during autocatalysis & $\begin{array}{l}\text { Process equipment to relieve (vent) } \\
\text { or contain force during autocatalysis }\end{array}$ \\
\hline
\end{tabular}

The chemical kinetics of HAN rapid decomposition has been studied to attempt to predict when the exothermic process accelerates into an explosion ${ }^{[23]}$. Although the kinetic mechanism of HAN decomposition comprises a number of steps, a lumped parameter model has been found useful to describe the reaction, with a temperature dependent rate constant, $k(T)$, as described in Equation (2), with $A$ referring to the frequency factor and $E_{a}$ to the activation energy for the lumped reaction.

$$
k(T)=A e^{\left(\frac{-E_{a}}{R T}\right)}
$$

Liu and coworkers ${ }^{[23]}$ have adapted an inflection point framework from Semenov to describe when the decomposition of HAN reaches a critical point, causing an explosion. The key equation involves $\frac{d \theta}{d \alpha}$, relating the change in temperature divided by the activation energy $\left(E_{a}\right), d \theta$, to the progress of the reaction, $d \alpha$, Equation (3). The roots of $\frac{d \theta}{d \alpha}$ and its second and third order derivatives are determined as a function of temperature and concentration. Details of the Semenov's approach to understanding thermal explosions have been reviewed by Merzhanov and Abramov. ${ }^{[24]}$

$$
\frac{d \theta}{d \alpha}=B\left[1-\frac{\theta-\frac{\theta_{S}}{\psi}}{(1-\alpha)^{n}\left(1+p \alpha^{n}\right) e^{-1 / \theta}}\right]
$$


Other variables and coefficients in Equation (3) include: $\theta_{\mathrm{s}}$, where s refers to the surrounding temperature; $\psi=Q V A C_{0}^{n} R / h s E_{a}$, where $Q$ is the heat of reaction, $V$ is the reaction volume, $A$ is the frequency factor, $C_{0}^{n}$ is the initial concentration of reagent raised to the power of the order of reaction, $n, R$ is the gas constant, $h$ is the heat transfer coefficient, and $s$ is the reactor surface area; the exothermicity of the reaction, $B=Q C_{0} R / \rho C_{v} E$, where $C_{v}$ is the specific heat, $\rho$ is the density, and $E$ is the total energy of the reaction; and $p$ is the autocatalytic reaction parameter calculated by fitting experimental data.

To model when the reaction rate becomes critical, system parameters, such as heat transfer coefficient, vessel dimensions, and ambient temperature must be included. From this analysis, trajectories of extreme temperature and infection point map out where a system remains subcritical, or passes through the critical, or supercritical regions during the course of a reaction. When systems, as defined by temperature and concentration, cross an inflection point trajectory as defined by Semenov and Liu, ${ }^{[23,24]}$ they become critical and the reaction rate will increase until the reagent is consumed. These results also explain the decrease in critical temperature with storage. The critical temperature of freshly prepared HAN is predicted to be $185^{\circ} \mathrm{C}$.

Results from the Semenov Theory, or critical analysis, discussed above, have been compared with computational fluid dynamics (CFD) in a scaled up system ${ }^{[20]}$. Liu's CFD analysis included convective flow, density gradients, and buoyancy effects. The Semenov results of tank temperature versus time tracked the average tank temperature from the CFD simulations, slightly lower than predictions for temperatures at the center of the tank. So, although Semenov's explosion analysis is appropriate for small scale laboratory experiments, scaled-up processes would benefit from a CFD simulation.

Values for thermophysical properties derived from calorimetry and kinetics experiments are given in Table 3. These values are used in the models of HAN decomposition behavior. 
Table 3. Thermophysical properties of HAN solutions

\begin{tabular}{|c|c|c|}
\hline Property & Value & Reference and Notes \\
\hline Specific heat (kJ/kgK) of liquid & $\begin{array}{l}4.3 \\
4.18\end{array}$ & $\begin{array}{l}\text { diluted } \mathrm{HAN}^{[23]} \\
\mathrm{HA} \text { assumed to be same as } \mathrm{H}_{2} \mathrm{O}^{[25]}\end{array}$ \\
\hline $\mathrm{pH} 50 \mathrm{wt} \% \mathrm{HA} / \mathrm{H}_{2} \mathrm{O}$ & 10.6 & [14] \\
\hline $\begin{array}{l}\text { Hydroxylamine } \\
\text { Molecular weight }(\mathrm{g} / \mathrm{mol}) \\
\text { Melting point }\left({ }^{\circ} \mathrm{C}\right) \\
\text { Boiling point }\left({ }^{\circ} \mathrm{C}\right) \\
\text { Explosion point }\left({ }^{\circ} \mathrm{C}\right) \\
\text { Density }(\mathrm{g} / \mathrm{mL}) \\
\text { Vapor pressure }(\mathrm{mmHg}) \\
\text { Critical concentration }\end{array}$ & $\begin{array}{l}33.03 \\
34 \\
110 \\
265,70 \text { (when heated in air) } \\
1.227 \\
10 \text { at } 47.2^{\circ} \mathrm{C} \\
70 \text { wt } \%\end{array}$ & [26] \\
\hline Heat of decomposition $(\mathrm{kJ} / \mathrm{mol})$ & $\begin{array}{l}118 \pm 20 \\
290 @ 1.5 \mathrm{M}\left[\mathrm{HNO}_{3}\right]\end{array}$ & $\begin{array}{l}\text { by adiabatic calorimetry }{ }^{[23]} \\
{[20]}\end{array}$ \\
\hline $\begin{array}{l}\text { Kinetic Model } \\
\text { Frequency factor }(A) \\
\text { reaction order }(n) \\
\text { reaction parameters }(p, m)\end{array}$ & $\begin{array}{l}(7.00 \pm 0.02) 10^{5} \\
0.55 \pm 0.06 \\
165 \pm 22,3.3 \pm 0.2\end{array}$ & by adiabatic calorimetry ${ }^{[23],[20]}$ \\
\hline $\begin{array}{l}\text { Activation Energies }\left(E_{a}\right)(\mathrm{kJ} / \mathrm{mol}) \\
\text { and Reaction Enthalpies }\end{array}$ & $\begin{array}{l}107,65 \\
61-71 \\
129 \text { for } 0.92-1.52 \text { M HAN(aq) } \\
66 \text { for } 1.58-1.74 \text { M HAN(aq) } \\
82 \pm 0.4,62 \pm 0.2 \\
105 \\
65\end{array}$ & $\begin{array}{l}\text { Pembridge \& Stedman for HA } \\
\text { oxidation by nitric \& nitrous acid } \\
\text { HAN dissociation (Shaw, Williams) } \\
\text { Schoppelrei, Brill, } \\
\text { concentration dependent } \\
\text { no } \mathrm{Fe}^{+3} \text {, with } \mathrm{Fe}^{+3}[20] \\
\text { nitrous acid formation(Rxn 7) } \\
\text { nitrous acid scavenging (Rxn 8) }\end{array}$ \\
\hline $\begin{array}{l}\text { Heats of formation, and entropies at } \\
25^{\circ} \mathrm{C} \text {, Cp(T) } 27-1227^{\circ} \mathrm{C} \text {. }\end{array}$ & $\begin{array}{l}\text { Gaseous } \mathrm{NO}_{\mathrm{x}} \\
\text { Solvated } \mathrm{H}_{\mathrm{x}} \mathrm{N}_{\mathrm{y}} \mathrm{O}_{\mathrm{z}}, \mathrm{HAN}\end{array}$ & $a b$ initio calculations ${ }^{[27]}$ \\
\hline
\end{tabular}

\subsection{METHODS FOR SAFE REMOVAL OR DISPOSAL}

Without stabilizers, $24 \mathrm{wt} \%$ freshly prepared HAN can be stored at room temperature, having a reactivity hazard of zero. However, $50 \%$ hydroxylamine in water will decompose even if stored at $10^{\circ} \mathrm{C}$ for a few months, and decompose much more energetically than freshly prepared solution ${ }^{[19]}$. This has been explained by using a critical temperature analysis, showing how the accumulation of reactive intermediates can lower the critical temperature. Hence it is necessary to deactivate the HAN in a controlled manner once the solution has been used in a process. Hydroxylamine decomposes by heat and in the presence of metal ions, particularly iron, but as discussed earlier, it is important to carefully monitor these variables to ensure a controlled reaction. Suggestions that have been made for HAN decomposition are (i) boiling $\mathrm{HAN}$ in open vessels; (ii) addition of $\mathrm{NaNO}_{2}$ to denitrify the solution; and (iii) addition of hydrogen peroxide to decompose HAN. 
HA solution will decompose in a glass vessel at a temperature of $136^{\circ} \mathrm{C}$. The activation energy of the decomposition process has been measured by Cisneros and colleagues as $140 \mathrm{~kJ} / \mathrm{mol}^{[19]}$. Thermal decomposition by boiling of $\mathrm{HAN} / \mathrm{HNO}_{3}$ in an open vessel must be done in a controlled manner to ensure that $\mathrm{H}_{2} \mathrm{O}$ doesn't boil away leaving a dangerously concentrated solution of $\mathrm{HAN} / \mathrm{HNO}_{3}$. The hazard may be reduced by bringing an aqueous solution of weak nitric acid to the boiling point and slowly add the concentrated $\mathrm{HAN} / \mathrm{HNO}_{3}$ remaining from the plutonium separation. The concentration of acid in the boiling mixture could be monitored outside of the glove box, allowing the addition of water if the $\mathrm{pH}$ drops below a predetermined level. Alternatively, if the HAN is at low concentration $(0.05 \mathrm{M})$, mixing with $1.0 \mathrm{M} \mathrm{HNO}_{3}$ has been found to allow complete and rapid decomposition after the mixture was brought to boiling and cooled. Thus, mixing of low concentration $\mathrm{HAN}$ with $2 \mathrm{M} \mathrm{HNO}_{3}$ has been suggested as a conservative approach to pretreatment of feed to the evaporators at Savannah River ${ }^{[28]}$

Oxidation of hydroxylamine with $\mathrm{OH} \bullet$ has been proposed by Karpel Vel Leitner and coworkers ${ }^{[29]}$ in the scrubbing of nitrogen from environmental systems. Karpel Vel Leitner generated $\mathrm{OH} \bullet$ in $\mathrm{H}_{2} \mathrm{O}_{2}$ using UV light and gamma irradiation. Both the concentrations of $\mathrm{HA}$ and $\mathrm{H}_{2} \mathrm{O}_{2}$ were very low in comparison with those used in the reduction of plutonium, 1 and $10 \mathrm{mM}$ respectively. However the HA was converted primarily to gaseous form, $\mathrm{N}_{2}$ and $\mathrm{N}_{2} \mathrm{O}$. Without the introduction of UV or gamma rays, $\mathrm{HA}$ appeared to be inert to $\mathrm{H}_{2} \mathrm{O}_{2}$. At $\mathrm{H}_{2} \mathrm{O}_{2}$ concentrations of $48 \mathrm{mM}$ and greater, the reaction of $\mathrm{H}_{2} \mathrm{O}_{2}$ with the $\mathrm{OH}$ • competed against the destruction of HA, and yields were reduced. This suggests that radiolysis of nitric acid solutions in plutonium separations, and generation of reactive radicals, may be important in the mechanism of HAN decomposition. However, other studies have shown that radiolytically produced $\mathrm{H}_{2}$, does not change dramatically when HAN is present, although some dilution arises because of the competition between $\mathrm{HAN}$ and $\mathrm{H}^{+}$for radiolytic $\mathrm{NO}_{2}{ }^{-[30]}$.

\subsection{ALTERNATIVE REDUCING AGENTS FOR PLUTONIUM}

Methods of separating plutonium from uranium in PUREX solvent extraction processes have been reviewed by Chesné ${ }^{[31]}$.

Sulfamic acid, $\mathrm{HSO}_{3} \mathrm{NH}_{2}$ or HSA, has been used for the same role as HAN in PUREX processing of $\mathrm{Pu}^{3+}$ solutions ${ }^{[32]}$. The impetus behind this switch was a reduction in the solid waste, ferrous sulfamate, which is generated in the HSA process. HSA reacts more quickly than HAN, but the latter has a greater dependence on ionic strength. If the sulfamate and $\mathrm{HAN}$ are used together, the $\mathrm{NH}_{2} \mathrm{SO}_{3}{ }^{-1}$ reacts with radiolytically generated $\mathrm{NO}_{2}^{-}$to form $\mathrm{N}_{2}$ and the sulfate ion, $\mathrm{SO}_{4}{ }^{2-}{ }^{-[28]}$. HAN has also found to be preferable to using a $\mathrm{Na}_{2} \mathrm{CO}_{3}$ or sodium tartarate scrub, the latter ending up as a sodium waste form ${ }^{[6]}$.

Hydrazinium nitrate will stabilize reduced $\mathrm{Pu}^{+3}$ in $\mathrm{HNO}_{3}$, at the same time destroying $\mathrm{HNO}_{2}$, Reactions (11 and 12) ${ }^{[33]}$. However, this process makes hydrazoic acid, $\mathrm{HN}_{3}$, which is toxic, volatile and explosive. The $\mathrm{HN}_{3}$ can itself react with $\mathrm{HNO}_{2}$, but will also volatilize and react in the gas phase with generated $\mathrm{NO}_{\mathrm{x}}$. Hydrazine is toxic and carcinogenic and because of this, and the hazards associated with exothermic release, has not received serious consideration in the United States.

$$
\begin{gathered}
\mathrm{N}_{2} \mathrm{H}_{5}^{+}+2 \mathrm{HNO}_{2} \rightarrow 2 \mathrm{H}_{2} \mathrm{O}+\mathrm{HN}_{3}+\mathrm{H}^{+} \\
\mathrm{HN}_{3}+\mathrm{HNO}_{2} \rightarrow \mathrm{N}_{2} \mathrm{O}+\mathrm{N}_{2}+\mathrm{H}_{2} \mathrm{O}
\end{gathered}
$$

An anion exchange resin has been used to separate plutonium from $\mathrm{HNO}_{3}$ solutions. Such liquid resins, such as trilaurylammonium nitrate, have been used for several years in Europe. However, the resin technology has not been adopted in the United States for a number of reasons. Tributyl phosphate used in liquid-liquid extraction has a much higher capacity. To get the same separation as with TBP, the resin has to be regenerated several times involving re-extraction with sulfuric acid and so the process becomes 
complicated. There are also concerns about degradation of the amine resins. A two phase system is less desirable for plutonium extraction because it can lead to the formation of interfacial cruds, emulsions, and film formation on the walls of the vessel. Other solid sorbents that have been considered include treated macroreticular resins, silica gels, inorganic ion exchange resins, and hydrous titanium dioxide. However, the many requirements for resin performance, regeneration, and waste form handling, make using these solids uneconomical ${ }^{[6]}$.

Scrubbing of $\mathrm{Pu}^{4+}$ can also be done directly, by forming sodium salts of organophosphates by mixing with solutions of sodium carbonate ${ }^{[6]}$.

\subsection{SAFE HANDLING OF HAN DURING EXPERIMENTAL STUDIES}

A number of tests have been developed by the United Nations to certify whether a particular chemical mixture must be deemed self-reactive ${ }^{[8]}$. These data are available for $50 \% \mathrm{HA} / \mathrm{H}_{2} \mathrm{O}$ and $85 \% \mathrm{HA} / \mathrm{H}_{2} \mathrm{O}$. To better understand the chemical processes that are occurring during decomposition, methods such as adiabatic calorimetry can be used to study reaction thermodynamics and kinetics and differential thermal analysis (DTA)/thermogravimetric analysis (TGA) and spectrophotometry can be used to sample a dynamic system ${ }^{[18]}$.

In adiabatic calorimetry, the sample temperature is increased in a stepwise manner until a reaction initiates. The temperature of onset at which this occurs, $T_{0}$, is defined at a predetermined increase in reaction mixture temperature, for instance $0.05^{\circ} \mathrm{C} / \mathrm{min}$. The reaction rate is determined by the rise in temperature coupled with the decrease in reagent concentration. However, a rate constant can be derived from the $d T / d t$ and $T_{\max }$ data ${ }^{[19]}$. For the lowest uncertainty in the results, the heat uptake by the cell should be minimized relative to that of the sample, often expressed as the $\phi$ ratio,

$\varphi=1+\frac{M_{\text {cell }} C_{\text {cell }}}{M_{\text {sample }} C_{\text {sample }}}$, where $M$ refers to mass and $C$ to specific heat.

Because they can build up and cause lowering of the onset or critical temperature for decomposition, reactive intermediates such as $\mathrm{HNO}_{2}$ need to be monitored in stored solutions of $\mathrm{HAN}$. $\mathrm{HNO}_{2}$ can be monitored spectrophotometrically in the UV at $372 \mathrm{~nm}$ with no interferences, or by the Griess method at $530 \mathrm{~nm}$. Raman spectroscopy is also possible. Vibrational frequencies include a symmetric stretch at $1047 \mathrm{~cm}^{-1}$, and broad $\mathrm{NH}$ and $\mathrm{OH}$ stretches occur at $3500 \mathrm{~cm}^{-1}$. High performance liquid chromatography (HPLC) and Ion Chromatography (IC) also allow monitoring of reaction progress ${ }^{[12]}$. Colorimetry for $\mathrm{NH}_{4}{ }^{+}, \mathrm{NO}_{2}{ }^{-}, \mathrm{NO}_{3}{ }^{-}, \mathrm{NH}_{2} \mathrm{OH}, \mathrm{N}_{2} \mathrm{H}_{4}$, gas chromatography for $\mathrm{N}_{2} \mathrm{O}$ and $\mathrm{N}_{2}$, and chemiluminesence for $\mathrm{NO}$ and $\mathrm{NO}_{2}$ are also useful ${ }^{[34]}$.

Safe handling of HAN and precursor solutions should include the following precautions, adapted from Harlow and colleagues. ${ }^{[4]}$

- $\quad$ Store HAN in the original and sealed manufacturer's shipping container. When HAN is removed, reseal the container to prevent concentration through evaporation.

- Only make up required solution volumes. For instance, stable $\left(\mathrm{NH}_{3} \mathrm{OH}\right) \cdot \mathrm{NO}_{3}$ can be prepared from the reaction of $\left(\mathrm{NH}_{3} \mathrm{OH}\right) \cdot \mathrm{SO}_{4}$ with $\mathrm{Ba}\left(\mathrm{NO}_{3}\right)_{2}$. For tests under neutral conditions, $\mathrm{HNO}_{2}$ can be made by adding $\mathrm{NaNO}_{2}$ to a solution of ammonium nitrate ${ }^{[10]}$. $\mathrm{HNO}_{2}$ is always present in concentrated $\mathrm{HNO}_{3}$.

- To minimize the accumulation of $\mathrm{HNO}_{2}$, protect solutions of $\mathrm{NaNO}_{2}$ and $\mathrm{HNO}_{3}$ from strong room light, and sparge solutions of $\mathrm{HNO}_{3}$ to remove NOx initially. Monitor $\mathrm{HNO}_{2}$ concentration. 
- Use glass or Teflon sheathed reaction vessels and thermocouples to reduce the possibility of catalysis. Use plastic containers and disposable plastic pipettes for transferring hydroxylamine solutions. Even a small surface area of a metal thermocouple will accelerate the HA decomposition reaction and reduce the threshold temperature for reaction. Silica coating is not effective at passivating the surface.

- Control heating conditions. Provide cooling if necessary.

- Do not directly add concentrated acid to HA.

- If the apparatus is to be shutdown, drain the chemicals from the system and flush the apparatus with water until neutral $\mathrm{pH}$ is achieved. Refill the apparatus with water for storage.

- Ensure that pressure relief is available on reaction vessels.

- Monitor stored solutions of HAN and HA for breakdown products and crystals.

- Dispose of chemicals expeditiously and following predetermined protocols. 


\section{NON-RADIOLOGICAL HAN DESTRUCTION}

\subsection{EXPERIMENTAL}

A number of methods can be used for HAN destruction, including heat, added reagents, and radiation. The most likely processes to be of use are listed in Table 4. The destruction involves oxidation of the HAN to $\mathrm{N}_{2} \mathrm{O}$ although $\mathrm{N}_{2}$ can also be produced, as shown in Reaction 13.

$$
\mathrm{HNO}_{2}+\mathrm{NH}_{3} \mathrm{OH}^{+} \rightarrow \mathrm{N}_{2} \mathrm{O}+2 \mathrm{H}_{2} \mathrm{O}+\mathrm{H}^{+}
$$

Table 4. Suggested methods to achieve HAN destruction

\begin{tabular}{|c|c|c|}
\hline Agent & Analysis & Specialized Equipment Needed \\
\hline heat & $\begin{array}{l}\text { reaction with } \mathrm{HNO}_{2} \text { (follow } \mathrm{HNO}_{2} \\
\text { spectroscopically) } \\
\text { reaction with } \mathrm{Fe}(\mathrm{III}) \text { to give } \mathrm{HNO}_{2} \\
\text { Ion chromatography } \\
\text { iodine selective electrode } \\
\text { QCL near IR }\end{array}$ & $\begin{array}{l}\text { hot plate } \\
\text { pH meter to monitor } \\
\text { NaOH for neutralization of HNO2 to } \\
\text { stabilize }\end{array}$ \\
\hline radiolysis & spectrophotometry & $\begin{array}{l}\text { Co-60 source } \sim 4 \text { h irradiation @ } \\
\$ 50 / \text { h } \\
\text { Pu (glove box) }\end{array}$ \\
\hline ozone & spectrophotometry & ozone generator \\
\hline $\mathrm{HNO}_{3}$ & spectrophotometry & $\begin{array}{l}\text { bring weak nitric to boiling point } \\
\text { and add } \mathrm{HAN} / \mathrm{HNO}_{3} \text { from process } \\
\text { dropwise } \\
\text { otherwise add } 1 \mathrm{M} \mathrm{HNO}_{3} \text { to mixture }\end{array}$ \\
\hline $\mathrm{Fe}(\mathrm{III})$ & Fe colorimetry or spectrophotometry & Source of Fe(III) \\
\hline $\mathrm{H}_{2} \mathrm{O}_{2}$ & spectrophotometry & UV light to generate $\mathrm{OH}$ radicals \\
\hline
\end{tabular}

There is no reliable spectroscopic measurement that can be used to directly observe hydroxylamine nitrate (HAN). Most methods rely on detection of a reagent that will react quickly with $\mathrm{HAN}$, such as $\mathrm{HNO}_{2}$ or $\mathrm{Fe}(\mathrm{III})$. If the reaction with $\mathrm{HNO}_{2}$ is being used to quantify the destruction of $\mathrm{HAN}$, the four lines in the UV associated with nitrous acid can be measured over time to determine the amount of $\mathrm{HNO}_{2}$ remaining in solution, namely: peaks centered at $346,358,371$, and $386 \mathrm{~nm}$. A small amount of acid is necessary to protonate the $\mathrm{NO}_{2}{ }^{-}$species.

At ORNL, spectrophotometric measurements of $\mathrm{HNO}_{2}$ were conducted using a Cary UV-Vis-NIR 5000 spectrophotometer manufactured by Varian, in a 1-cm-pathlength reduced volume quartz cell. About $1 \mathrm{~mL}$ of solution was used for each measurement. Besides the four wavelengths given earlier, the absorbance at $400 \mathrm{~nm}$ was also recorded as this allows background correction in reacting systems, for instance, those that produce bubbles and, hence, attenuation of the UV signal.

A test run was done using $\mathrm{HAN}$ in contact with $\mathrm{HNO}_{2}$ in a weakly acidified system and the results are plotted in the Figure 3. The HAN was in excess and so the $\mathrm{HNO}_{2}$ was consumed completely. However, in most cases, one would want excess $\mathrm{HNO}_{2}$ to determine the initial composition of HAN. The example 
shows that the addition of nitrite to HAN achieves destruction within minutes. Although the reaction often took less time, an incubation period in the analysis solution of 12 minutes allows for complete reaction between $\mathrm{HNO}_{2}$ and $\mathrm{HAN}$.

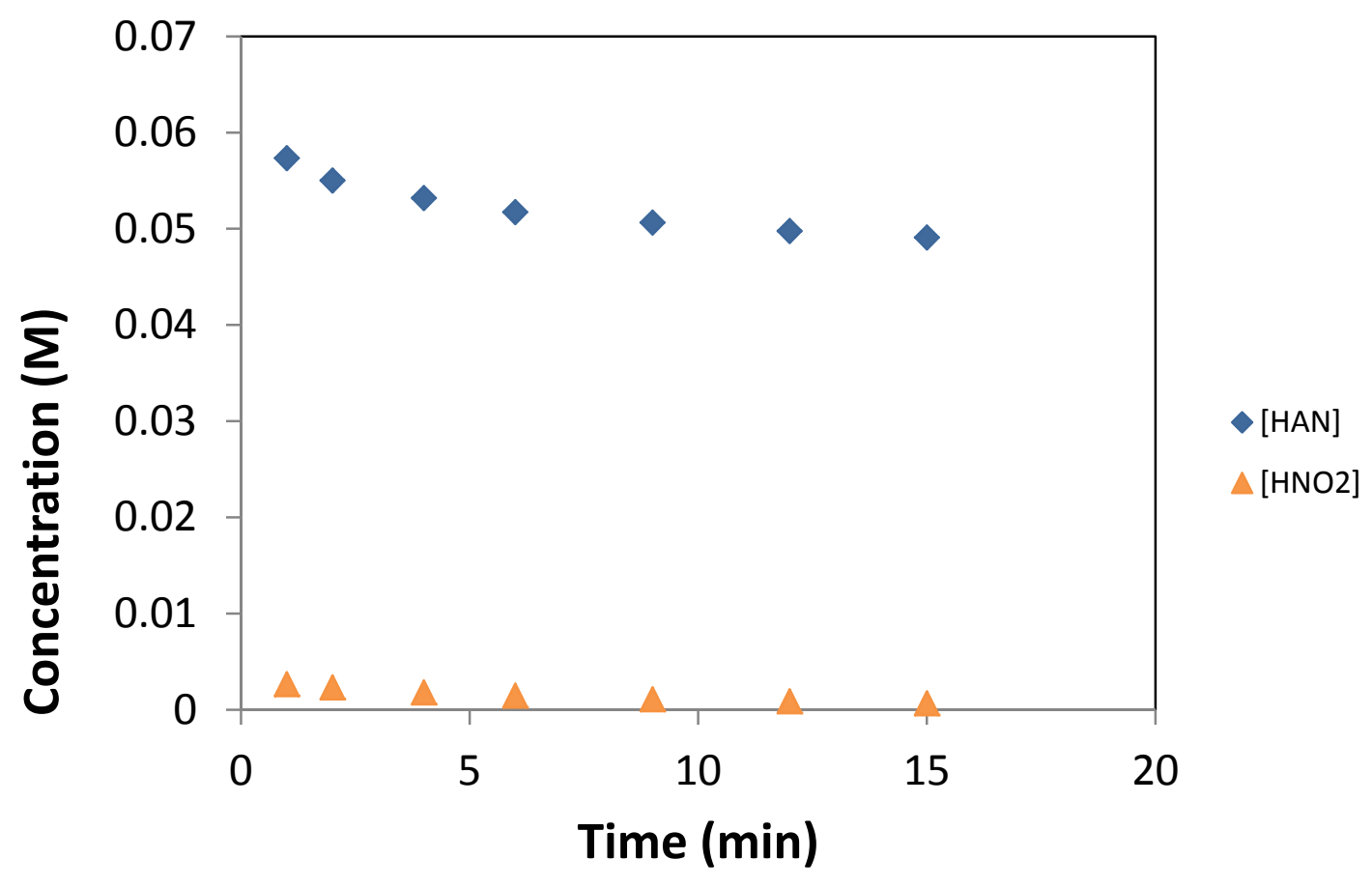

Figure 3. Monitoring of $\mathrm{HAN}$ through the use of $\mathrm{HNO}_{2} \mathrm{UV}$ spectroscopy, showing a reaction in the Cary spectrophotometer cuvette.

Following the proof of principle test, a calibration curve was taken with various amounts of acidified $\mathrm{HNO}_{2}$, covering the dynamic range of the experiments investigating HAN destruction. The concentration of $\mathrm{HNO}_{3}$ used in calibration was $0.54 \mathrm{M}$. Trendlines through the calibration data were close to linear, and did not go through the origin because of the background absorbance of $\mathrm{HNO}_{3}$ and its equilibration with $\mathrm{HNO}_{2}$. The slopes of the highest absorbance peaks were very similar and higher than at the lower absorbance peaks. Linear fits are given in Figure 4, and these are used in the conversion of absorbance to concentration results. The absorptivities were compared with those published by Stutz et al. ${ }^{[35]}$ and Zuo and Deng, ${ }^{[36]}$ and were found to fall closer to the latter. Depending on the concentrations of other species in solution, the absorptivities changed by a factor of two, with the peaks at 358 and $371 \mathrm{~nm}$ being the most intense.

In some of the tests, $2 \mathrm{M}$ hydroxyl amine nitrate was obtained from the Radiochemical Engineering Development Center (REDC), but earlier tests followed the synthetic procedure from hydroxylamine sulfate (MP Biomedicals LLC, Lot 5099J) as outlined by Bennet and coworkers. ${ }^{[10]}$ An amount of $\mathrm{Ba}\left(\mathrm{NO}_{3}\right)_{2}$ (Allied Chemical and Dye Corporation, Lot H099), $6.593 \mathrm{~g}$, was dissolved in $50 \mathrm{~mL}$ deionized water, DI (18 M $\Omega \cdot \mathrm{cm})$, assisted by $1 \mathrm{~h}$ of sonication. Of the resulting solution, $20 \mathrm{~mL}$ was mixed with $20 \mathrm{~mL}$ of hydroxylamine sulfate $(8.2787 \mathrm{~g}$ in $100 \mathrm{~mL}$ DI) immediately resulting in a white precipitate of $\mathrm{BaSO}_{4}$. The resulting HAN solution $(\sim 0.6 \mathrm{M})$ was filtered through Whatman\#42 filter paper and used without further purification. Other reagents used in these tests were $\mathrm{H}_{2} \mathrm{O}_{2}(30 \% \mathrm{w} / \mathrm{w}$ Amresco Lot \#2674C256) and $\mathrm{FeCl}_{3} \cdot 6 \mathrm{H}_{2} \mathrm{O}$ (Sigma-Aldrich Lot\#73297MJV). 


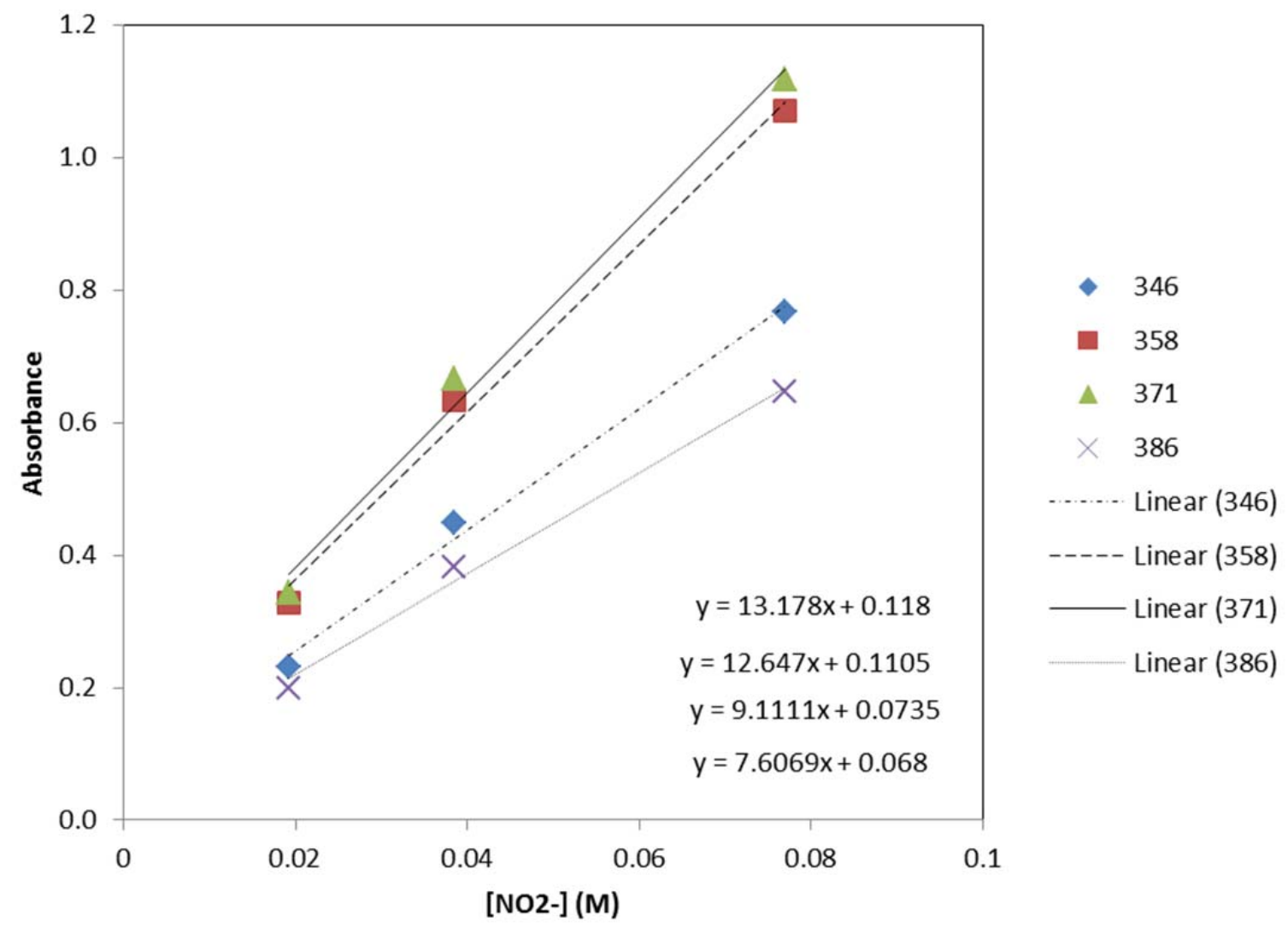

Figure 4. Calibration of the measurement of nitrous acid in the Cary UV spectrophotometer, absorbance versus nitrite ion concentration.

In addition to the spectrophotometric method of analysis, titration of HAN solutions with $0.1 \mathrm{M} \mathrm{NaOH}$ was carried out to determined bound acid (in the form of $\mathrm{HAN}$ ) and free acid, $\mathrm{HNO}_{3}$. Titrations were used to analyze the thermal degradation of HAN from 24.1 (ambient lab temperature) to $95^{\circ} \mathrm{C}$.

\subsection{RESULTS AND DISCUSSION}

\subsubsection{Acid Treatment}

The degradation of HAN in the presence of nitric acid was investigated for $62 \mathrm{mM}$ HAN in acid concentrations ranging from 2 to $849 \mathrm{mM}$. These experiments were carried out at room temperature, or $20^{\circ} \mathrm{C}$. At low acid concentrations (less than $1 \mathrm{M}$ ), $\mathrm{HNO}_{2}$ remains stable for several hours. Hence, nitric acid and $\mathrm{NaNO}_{2}$, as the analyte, were mixed in the spectrophotometer cuvette. Time zero for the reaction occurred when the mixture was spiked with the HAN. An example of peak heights from the spectra taken during the reaction of $\mathrm{HAN}$ and $\mathrm{HNO}_{2}$ is shown in Figure 5. The absorbance of $\mathrm{HNO}_{2}$ remained stable up until the point when HAN was added, at 4 min in this case. Spectra were taken every 2-3 minutes after the addition, until the signal again remained stable. The HAN in solution can be determined by the difference in $\mathrm{HNO}_{2}$ signal, initially, minus the absorbance at long times. Trends were similar for the four wavelengths being monitored, although the absorptivity was different for each. 


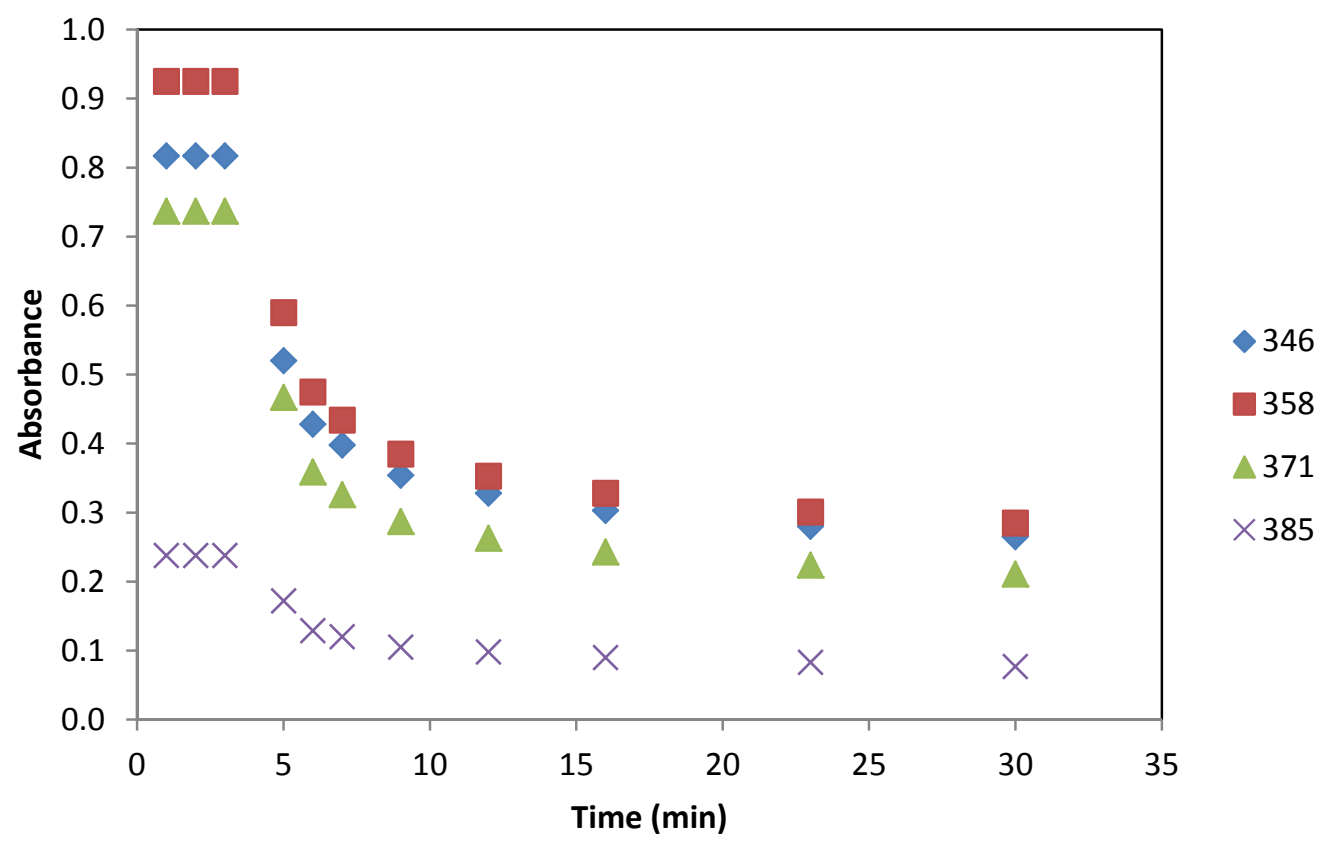

Figure 5. Absorbance of $\mathrm{HNO}_{2}$ as a function of time in $17 \mathrm{mM} \mathrm{HNO}_{3}$. $\mathrm{HAN}$ at $56 \mathrm{mM}$ was added at 4 minutes.

The degradation of $\mathrm{HAN}$ in $\mathrm{HNO}_{3}$, with acid concentrations from $2 \mathrm{mM}$ to $4.2 \mathrm{M}$, was measured, as shown in Figure 6. The residual HAN is very similar for the curves at lower acid concentration, showing little degradation to a value of $0.044 \pm 0.06 \mathrm{M}$ (or a drop of 22\%). The shapes of the curves at lower acid concentration are slightly different, perhaps arising from the fact that these were unstirred mixtures. All the solutions had reached steady state at 20 minutes. With $4.2 \mathrm{M} \mathrm{HNO}_{3}$, however, the HAN is quickly destroyed and the $\mathrm{HNO}_{2}$ absorbance remains high throughout the test. 


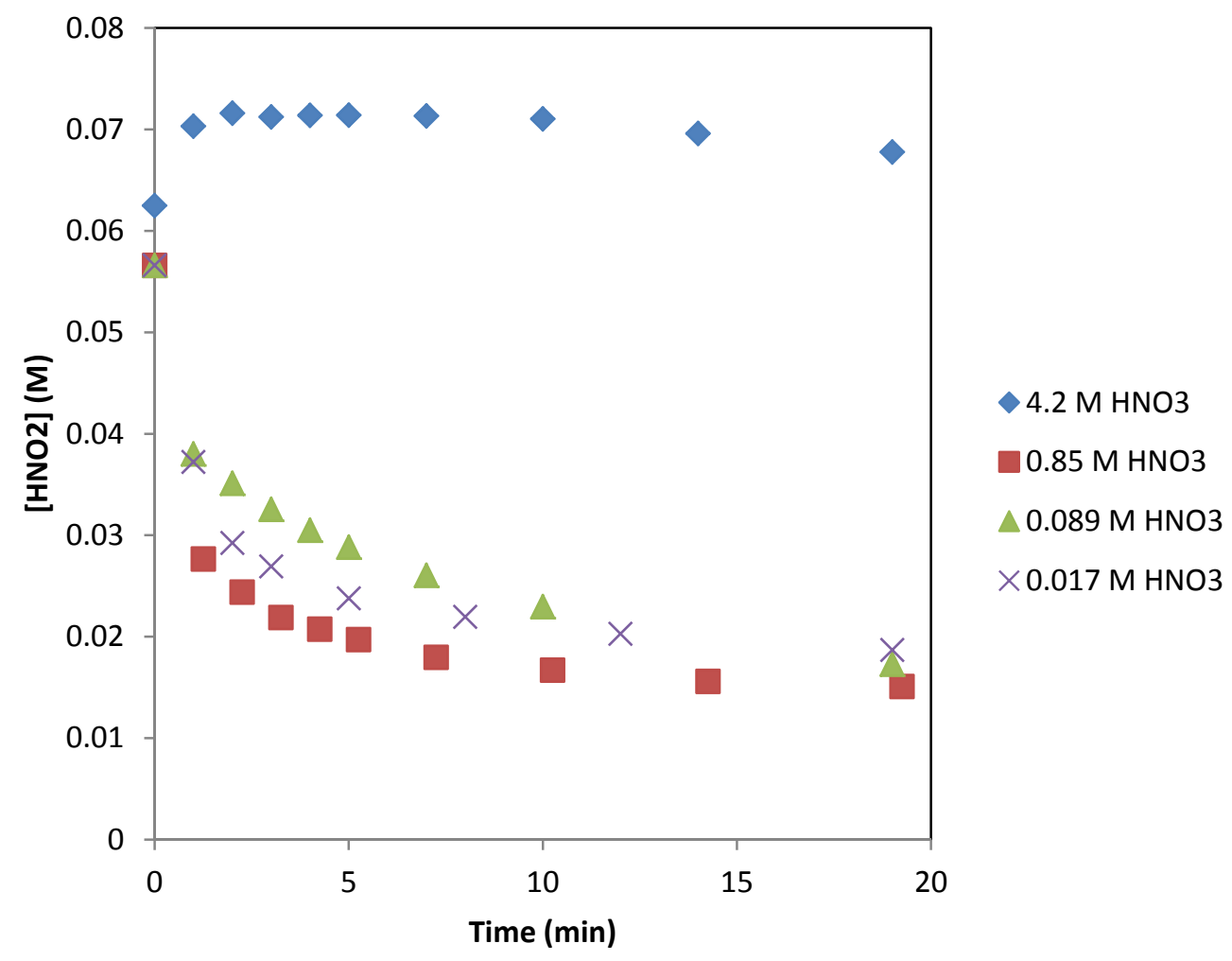

Figure 6. Concentration of $\mathrm{HNO}_{2}$ versus time (min) showing residual $\mathrm{HAN}$ in nitric acid solution.

The tests were repeated with 5 times more concentrated HAN, about $231 \mathrm{mM}$, in nitric acid from $7.7 \mathrm{mM}$ to $3.1 \mathrm{M}$. Reaction between the HAN and the $\mathrm{HNO}_{2}$ was vigorous, generating bubbles and affecting the spectroscopy, because of the higher concentrations of reagents. However, absorbance values taken at longer times (20 minutes) were obtained under quiescent conditions and so reflect the amount of steadystate residual HAN after decomposition. The data were plotted on a semi-log scale, extrapolated to $t=0.1 \mathrm{~s}$ to obtain the initial absorbance, as this could not be read directly for high concentrations of $\mathrm{HNO}_{2}$. At $7.7 \mathrm{mM} \mathrm{HNO}_{3}$, the acid was not sufficient to protonate all of the $\mathrm{NO}_{2}^{-}$, degrading the resolution of the four peaks in the UV. The results are summarized in Table 5.

Table 5. Reduction of $\mathrm{HAN}$ in $\mathrm{HNO}_{3}$ as a function of [HAN] and $\left[\mathrm{HNO}_{3}\right]$ at room temperature

\begin{tabular}{cccc}
\hline [HAN] (mM) & HNO $_{3}(\mathbf{m M})$ & $\begin{array}{c}\text { \% reduction at steady } \\
\text { state }\end{array}$ & $\begin{array}{c}\text { Time for reaction } \\
\text { completion (min) }\end{array}$ \\
\hline 62 & $17-85$ & $22 \pm 3$ & 15 \\
62 & 4200 & 100 & 2 \\
231 & 7.7 & 23 & 15 \\
231 & 38 & $57 \pm 7$ & 20 \\
231 & 385 & $43 \pm 6$ & 3 \\
231 & 3100 & $80.8 \pm 0.8$ & $\geq 17$ \\
\hline
\end{tabular}

The addition of acid decomposes HAN, even at low concentrations, but is limited until $\left[\mathrm{HNO}_{3}\right]$ is above $1 \mathrm{M}$. The concentration of HAN, 62 or $231 \mathrm{mM}$, has little effect at low acid concentrations, both showing a depletion of about 22\% after 15 minutes. At higher concentrations of acid, the $62 \mathrm{mM}$ HAN was found to decompose completely, but the 231 mM HAN showed 80\% decomposition, even after 17 min. Steady- 
state had not yet been reached in this test, suggesting that higher values for decomposition might have been observed had the reaction been followed for a longer time.

\subsubsection{Thermal Treatment}

A series of tests was carried out on the heating of $\mathrm{HAN}$ in the presence of $\mathrm{HNO}_{3}$, varying $\mathrm{HNO}_{3}$ concentration and temperature. Analysis used the spectrophotometric method discussed in Section 2.2.1. The results are shown in Figure 7, for temperatures from 20 to $90^{\circ} \mathrm{C}$, and acid concentrations from $0.5 \mathrm{M}$ to $2 \mathrm{M} \mathrm{HNO}_{3}$.

Heating of HAN on its own, with no acid present, showed no significant breakdown even at temperatures up to $90^{\circ} \mathrm{C}$, when assayed using the reaction of $\mathrm{HNO}_{2}$. Although spectrophotometry showed shifts in frequencies of the nitrous acid peaks, the $\mathrm{HNO}_{2}$ signal levels were low suggesting $\mathrm{HAN}$ remained after thermal treatment to react with the $\mathrm{HNO}_{2}$.

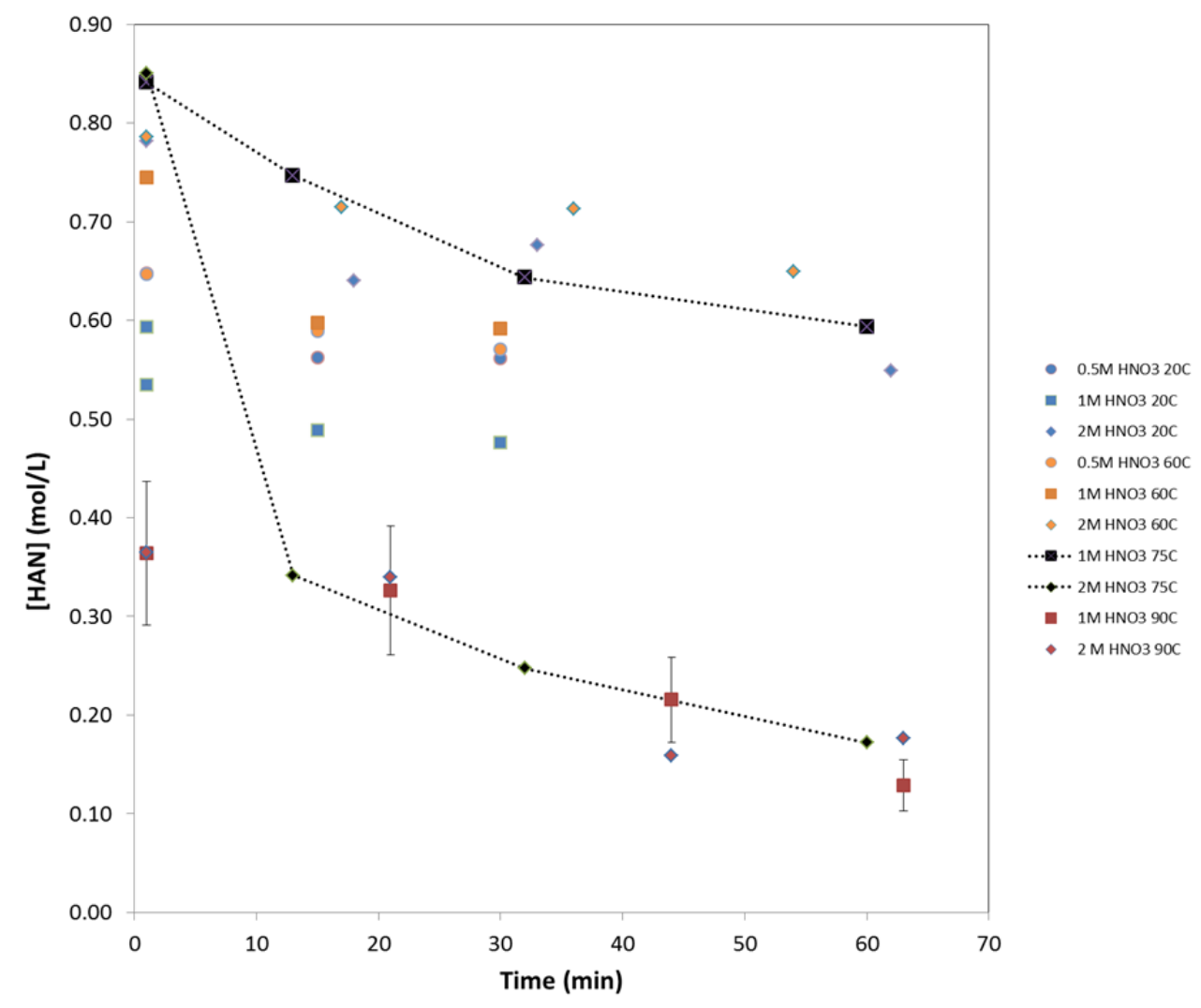

Figure 7. Concentration of $\mathrm{HAN}$ as a function of time (min) in the presence of heated $\mathrm{HNO}_{3}$.

HAN concentrations shown in Figure 7 were derived from the change in $\mathrm{HNO}_{2}$ over time. The results indicate a large reduction in $\mathrm{HAN}$ at $75^{\circ} \mathrm{C}$ in $2 \mathrm{M} \mathrm{HNO}_{3}$, and at both $1 \mathrm{M}$ and $2 \mathrm{M} \mathrm{HNO}_{3}$ at $90^{\circ} \mathrm{C}$.

However, the spectrophotometric results were complicated by the fact that $\mathrm{HNO}_{2}$ itself is produced during the decomposition of HAN, Reaction (9), perhaps giving rise to apparent concentrations greater than $0.5 \mathrm{M}$. The $\mathrm{HNO}_{2}$ also slowly reacts in air and $\mathrm{HNO}_{3}$, adding uncertainty to the analysis of HAN determined by different in $\mathrm{HNO}_{2}$ signal. Hence, the slow downward trend observed in HAN concentration was likely an artifact of the measurement, most obvious at low concentrations of $\mathrm{HNO}_{3}$ and $\mathrm{HAN}$. 
The HAN was also analyzed by titration of $\mathrm{HNO}_{2}$. In this case, the $\mathrm{HAN}$ and the $\mathrm{HNO}_{3}$ mixtures were heated for at least 15 minutes to a predetermined temperature $60-95^{\circ} \mathrm{C}$ in a vessel held in a thermostatted water bath. The mixing of $\mathrm{HAN}$ and $\mathrm{HNO}_{3}$ was followed by addition of $\mathrm{HNO}_{2}$ and analysis of free acid by titration with $\mathrm{NaOH}$. In theory, the free acid would show two endpoints, one corresponding to the pKa of the weak acid, and the second to the $\mathrm{pKa}$ of the $\mathrm{HNO}_{3}$ giving a sharp endpoint. However, the first endpoint was gradual, ranging between 4.1 and 5.2 as recorded by the Metro-ohm automatic titrator, and so could have either corresponded to excess HAN ( $\mathrm{pKa}=5.94)$ or to $\mathrm{HNO}_{2}(\mathrm{pKa}=3.14)$.

Hence, the heating experiments were repeated, with analysis by Ion Chromatography (IC) for HAN. The results are shown in Table 6 and in Figures 8, 9 and 10.

Table 6. HAN Concentration (M) in $\mathrm{HAN}+\mathrm{HNO}_{3}$ mixtures as a function of temperature

\begin{tabular}{|c|c|c|c|c|c|c|c|c|c|c|}
\hline Temperature & Time & & & $\begin{array}{c}{\left[\mathrm{HNO}_{3}\right]} \\
\text { (M) }\end{array}$ & & & & & & \\
\hline$\left({ }^{\circ} \mathrm{C}\right)$ & $(\min )$ & 1.0 & 2.0 & 2.2 & 2.4 & 2.6 & 2.8 & 2.9 & 3.0 & 8.0 \\
\hline \multirow[t]{3}{*}{$21.6-24.1$} & $0 \min$ & 0.513 & 0.439 & & & & & & 0.542 & $0.002^{\#}$ \\
\hline & $30 \mathrm{~min}$ & 0.439 & 0.442 & & & & & & 0.553 & \\
\hline & $60 \mathrm{~min}$ & 0.343 & 0.532 & & & & & & 0.551 & \\
\hline 60 & & 0.510 & & & & & & & & \\
\hline \multirow[t]{3}{*}{75} & $0 \min$ & 0.490 & 0.491 & 0.478 & 0.533 & 0.570 & 0.607 & 0.277 & 0.002 & \\
\hline & $30 \mathrm{~min}$ & 0.508 & 0.567 & 0.558 & 0.554 & 0.579 & 0.580 & 0.444 & 0.002 & \\
\hline & $60 \mathrm{~min}$ & 0.529 & 0.565 & 0.529 & 0.596 & 0.555 & 0.559 & 0.346 & 0.002 & \\
\hline \multirow[t]{3}{*}{80} & 3 min & 0.572 & 0.460 & & & & & & & \\
\hline & $30 \mathrm{~min}$ & 0.599 & 0.493 & & & & & & & \\
\hline & $60 \mathrm{~min}$ & 0.612 & 0.522 & & & & & & & \\
\hline 90 & & 0.545 & & & & & & & & 0.002 \\
\hline 95 & & & & & & & & & & \\
\hline
\end{tabular}

\footnotetext{
\# IC detection limit for HAN (mol/L). The IC had an accuracy of $\pm 10 \%$.

Data were not collected at all temperatures and concentrations of $\mathrm{HNO}_{3}$.
} 

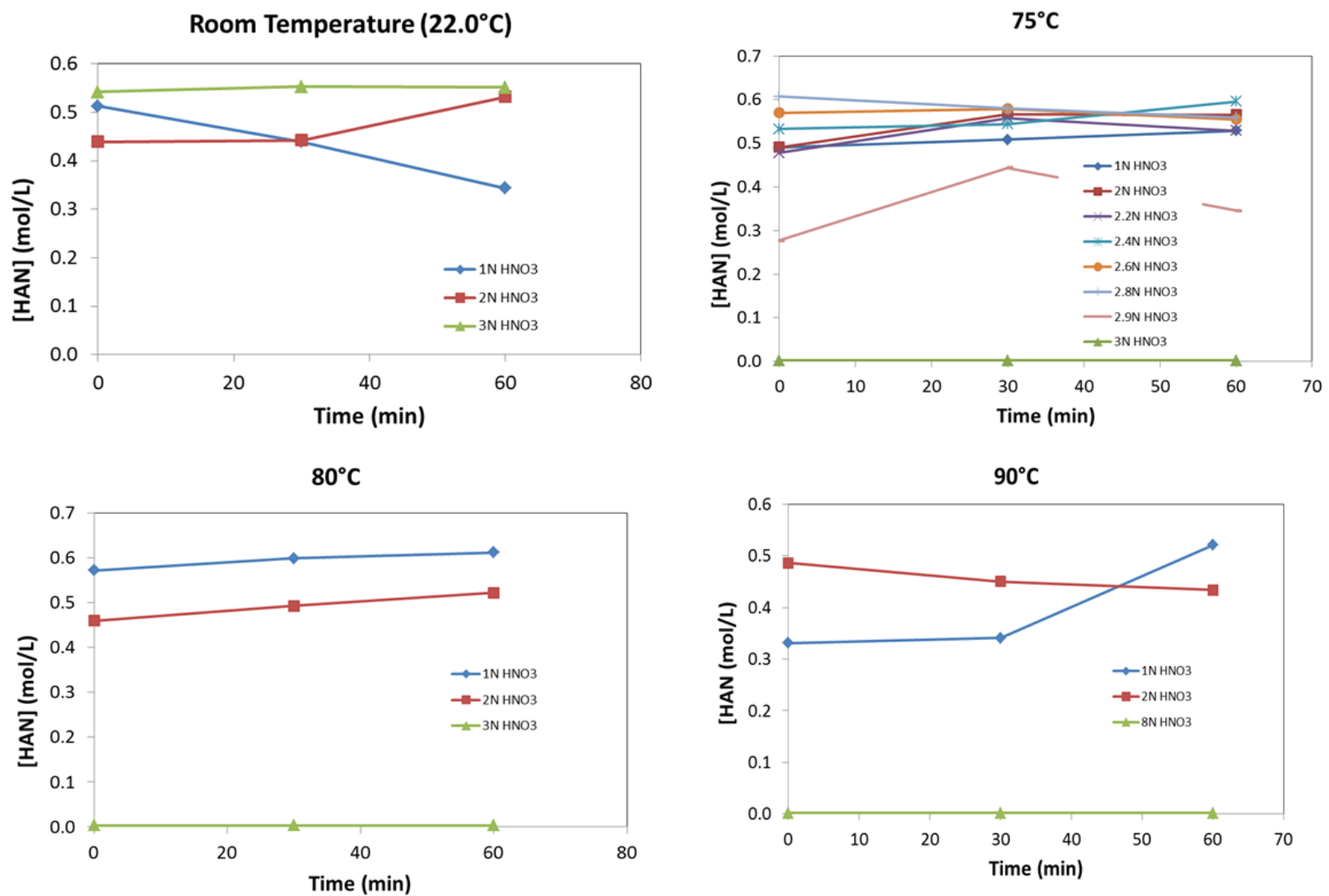

Figure 8. HAN (mol/L) after contact with $\mathrm{HNO}_{3}$ for up to $60 \mathrm{~min}$. Data were taken for temperatures from 22 to $90^{\circ} \mathrm{C}$.

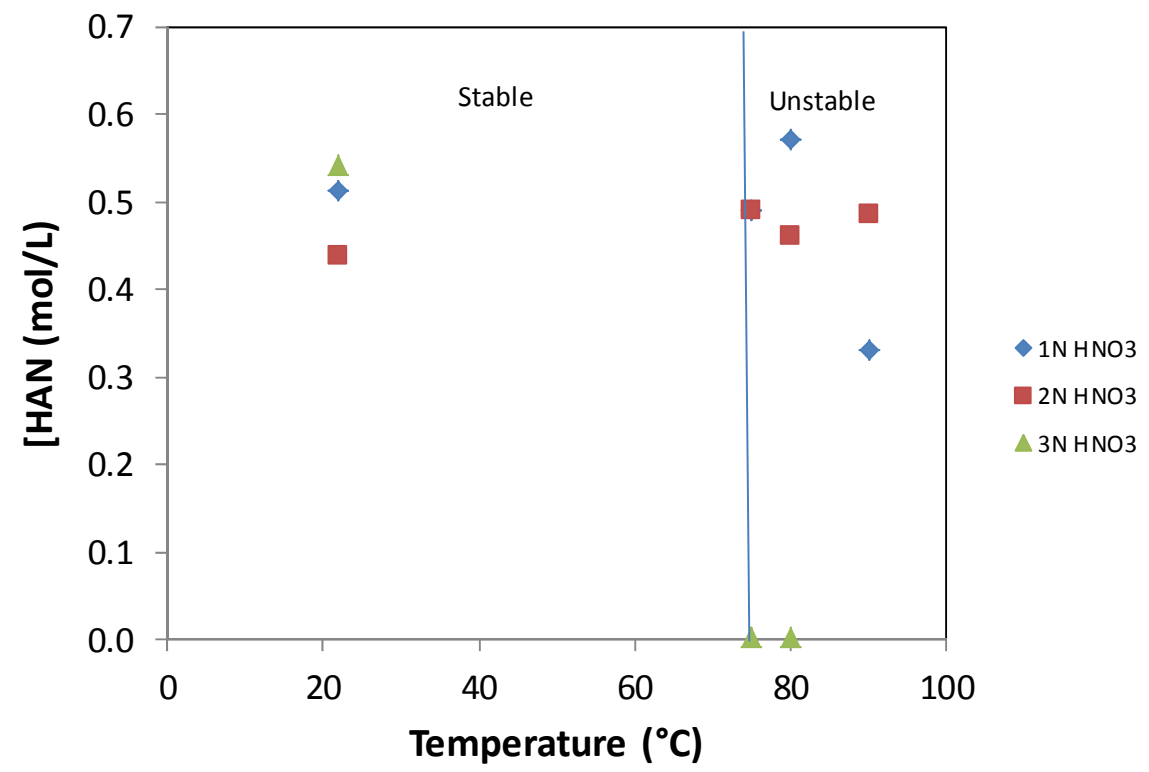

Figure 9. Concentration of $\mathrm{HAN}(\mathrm{mol} / \mathrm{L})$ as a function of reaction temperature with samples taken immediately after contact with $\mathrm{HNO}_{3}$. 
At room temperature, $\mathrm{HAN}$ was found to react only with $8 \mathrm{M} \mathrm{HNO}_{3}$. However, $\mathrm{HAN}$ reacts rapidly with $3 \mathrm{M} \mathrm{HNO}_{3}$ and above at $75^{\circ} \mathrm{C}$, as shown in Figures 8 and 9. Results presented in Table 6 indicate that some reaction is seen at $2.9 \mathrm{M}$, but none at $2.8 \mathrm{M}$. The reaction of $\mathrm{HAN}$ with $3 \mathrm{M} \mathrm{HNO}_{3}$ was observed to be very rapid as shown by the comparison of the lines in Figure 10 ; above $75^{\circ} \mathrm{C}$ the first data showed immediate reaction, with little subsequent change over the period of an hour.

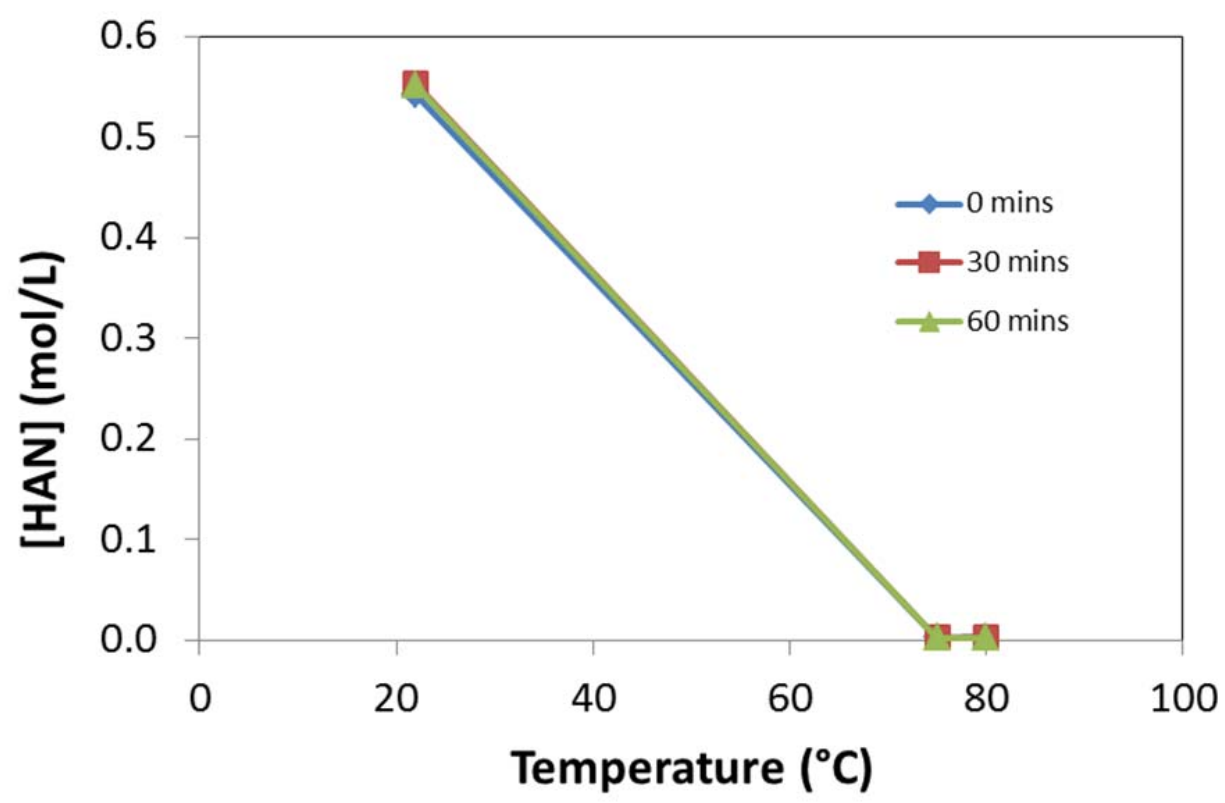

Figure 10. HAN (mol/L) after reacting with $3 \mathrm{M} \mathrm{HNO}_{3}$ as a function of temperature.

\subsubsection{Dropwise Addition of $\mathrm{HAN}$ into Boiling $\mathrm{HNO}_{3}$}

A suggested method for decomposing HAN is to add it in small increments to boiling $\mathrm{HNO}_{3}$ in a controlled manner. A test series was set up using a heated water bath on a hot plate, into which was suspended a test tube containing $\mathrm{HNO}_{3}(2 \mathrm{M})$. The temperature of the water bath was monitored using a thermocouple and was maintained at greater than $99^{\circ} \mathrm{C}$. The temperature of the bath did drop momentarily during the occasional replenishment of water, but these additions were restricted so that temperatures never dropped below $95^{\circ} \mathrm{C}$. The initial volume of solution was $10 \mathrm{~mL}$, so sub-mL additions of HAN had little effect on the solution temperature. Samples were taken for UV analysis before each addition of $\mathrm{HAN}$ and added to an analysis mixture of $\mathrm{HNO}_{3}$ and $\mathrm{HNO}_{2}$. The $\mathrm{HAN}$ was added in $500 \mathrm{uL}$ aliquots every 5 minutes, and $500 \mathrm{uL}$ samples were extracted from the solution every five minutes. Because of sampling, the concentration of $\mathrm{HNO}_{3}$ decreased from 1.9 to $1.2 \mathrm{M}$ during the experiment. Heat was observed to also decompose the $\mathrm{HNO}_{2}$, and so the additional step of preparing sampling solutions was required prior to spectrophotometric analysis.

Visual observations included the fact that the solution in the test tube liberated gas when the aliquots of $\mathrm{HAN}$ came into contact with the heated $\mathrm{HNO}_{3}$. The fact that the $\mathrm{HAN}$ was quickly decomposed was confirmed by the UV analysis. Boiling of nitric acid solutions also concentrated the acid, encouraging further increases in the rate of reaction. The calculated HAN concentration in the boiling $2 \mathrm{M} \mathrm{HNO}_{3}$ is compared with the measured HAN in Figure 11. Although the data show scatter, likely arising from difficulties in sampling a boiling fluid by pipette, it can be seen that the measured amount of HAN is much less than the added amount, particularly after boiling for more than half an hour. 


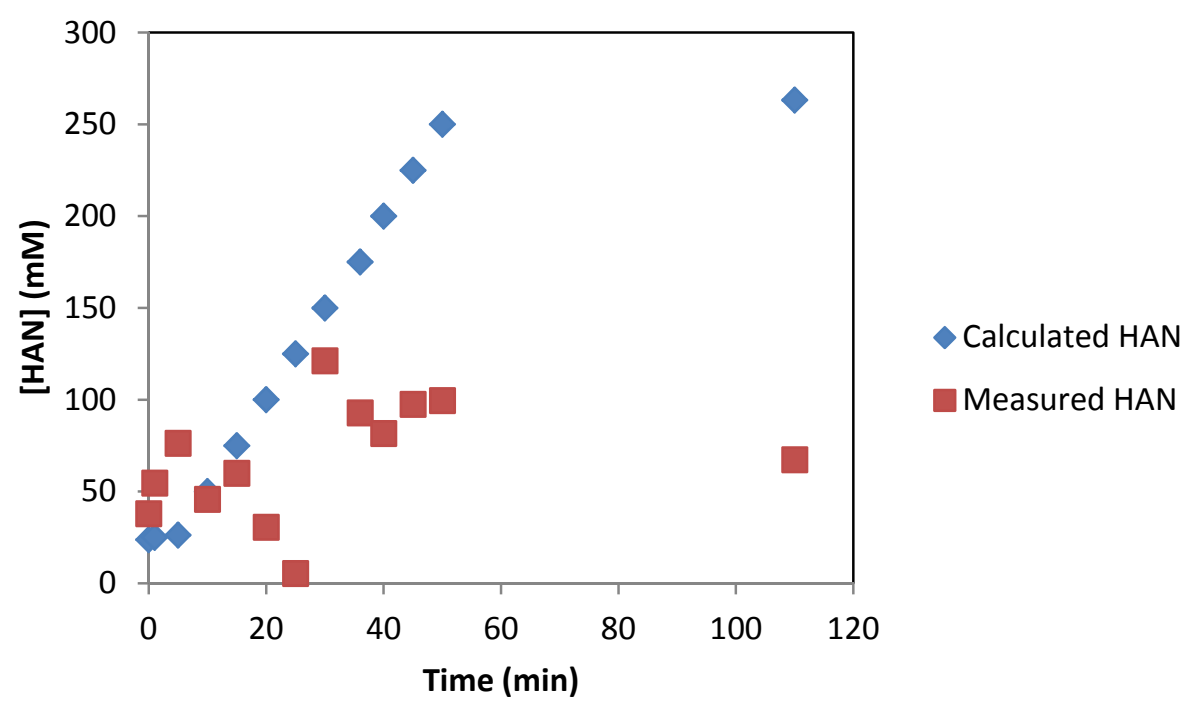

Figure 11. HAN concentrations $(\mathrm{mM})$ as a function of time $(\mathrm{min})$ as calculated from the amount added to boiling $2 \mathrm{M} \mathrm{HNO}$ and the concentration measured through $\mathrm{HNO}_{2}$ spectrophotometry.

The addition of HAN to heated $\mathrm{HNO}_{3}$ was repeated at higher acid concentrations, 2 to $6 \mathrm{M}$, and with $1 \mathrm{~mL}$ of $0.5 \mathrm{M}$ HAN added to each time. Reactivity was quickly assessed by looking for the liberation of gas from the vessel. This appears to be a conservative approach to assessing reactivity, as conditions of temperature and $\mathrm{HNO}_{3}$ concentration where gas is liberated appear to be higher than results reported in section 2.2.3. Observations are presented in Table 7.

Table 7. Mixtures of $\mathrm{HAN}$ and $\mathrm{HNO}_{3}$ with visible reaction

\begin{tabular}{|c|c|c|c|c|}
\hline Temperature & \multicolumn{4}{|c|}{$\left[\mathrm{HNO}_{3}\right](\mathrm{M})$} \\
\hline$\left({ }^{\circ} \mathrm{C}\right)$ & 2.0 & 3.0 & 4.0 & 5.0 \\
\hline 95 & bubbling & \multicolumn{3}{|c|}{ rapid evolution of brown gas } \\
\hline 90 & slight bubbling & \multicolumn{3}{|c|}{ rapid evolution of brown gas } \\
\hline 85 & $\begin{array}{l}\text { no observable } \\
\text { reaction }\end{array}$ & $\begin{array}{l}\text { no observable } \\
\text { reaction }\end{array}$ & \multicolumn{2}{|c|}{ rapid evolution of brown gas } \\
\hline 80 & & & vigorous bubbling & $\begin{array}{l}\text { rapid evolution of } \\
\text { brown gas }\end{array}$ \\
\hline 75 & & $\begin{array}{l}\text { no observable } \\
\text { reaction }\end{array}$ & slight bubbling & $\begin{array}{l}\text { rapid evolution of } \\
\text { brown gas }\end{array}$ \\
\hline 70 & & & slight bubbling & vigorous bubbling \\
\hline 65 & & & & vigorous bubbling \\
\hline 60 & & & & slight bubbling \\
\hline
\end{tabular}




\subsubsection{Reaction with $\mathrm{UV}$ and $\mathrm{H}_{2} \mathrm{O}_{2}$}

Direct reaction with hydrogen peroxide is not expected to cause much degradation of HAN, but the products of $\mathrm{H}_{2} \mathrm{O}_{2} \mathrm{UV}$ photolysis, $\mathrm{OH}$ radical, should act quickly to oxidize HAN. A series of experiments used an Oriel mercury arc lamp to provide radiolysis at UV wavelengths down to $248 \mathrm{~nm}$. The lamp also produces lines in the visible, and while these were not filtered, they were not expected to contribute to $\mathrm{OH} \bullet$ production. HAN and $\mathrm{H}_{2} \mathrm{O}_{2}$ were combined in equimolar concentrations, in DI.

Results from the UV photolysis experiments are presented in Figure 12. The degradation of HAN with applied UV follows an exponential decay. Data for addition of $\mathrm{H}_{2} \mathrm{O}_{2}$ without $U V$, and $U V$ without $\mathrm{H}_{2} \mathrm{O}_{2}$ are also shown on the chart. The error in the measurement arises primarily from the evaporation and concentration of solution while being irradiated. Gravimetric measurements after photolysis showed a $15 \%$ evaporation rate after 5 hours of irradiation, or approximately 3\% per hour.

Results from control experiments were carried out without UV and without $\mathrm{H}_{2} \mathrm{O}_{2}$ are also shown on Figure 12. The control experiment without UV did now show any degradation arising from unirradiated $\mathrm{H}_{2} \mathrm{O}_{2}$. In the control experiment with $\mathrm{UV}$ and no $\mathrm{H}_{2} \mathrm{O}_{2}$, there may have been a small decrease in HAN from the photolysis of $\mathrm{H}_{2} \mathrm{O}$, but not enough to quantify a rate of reaction.

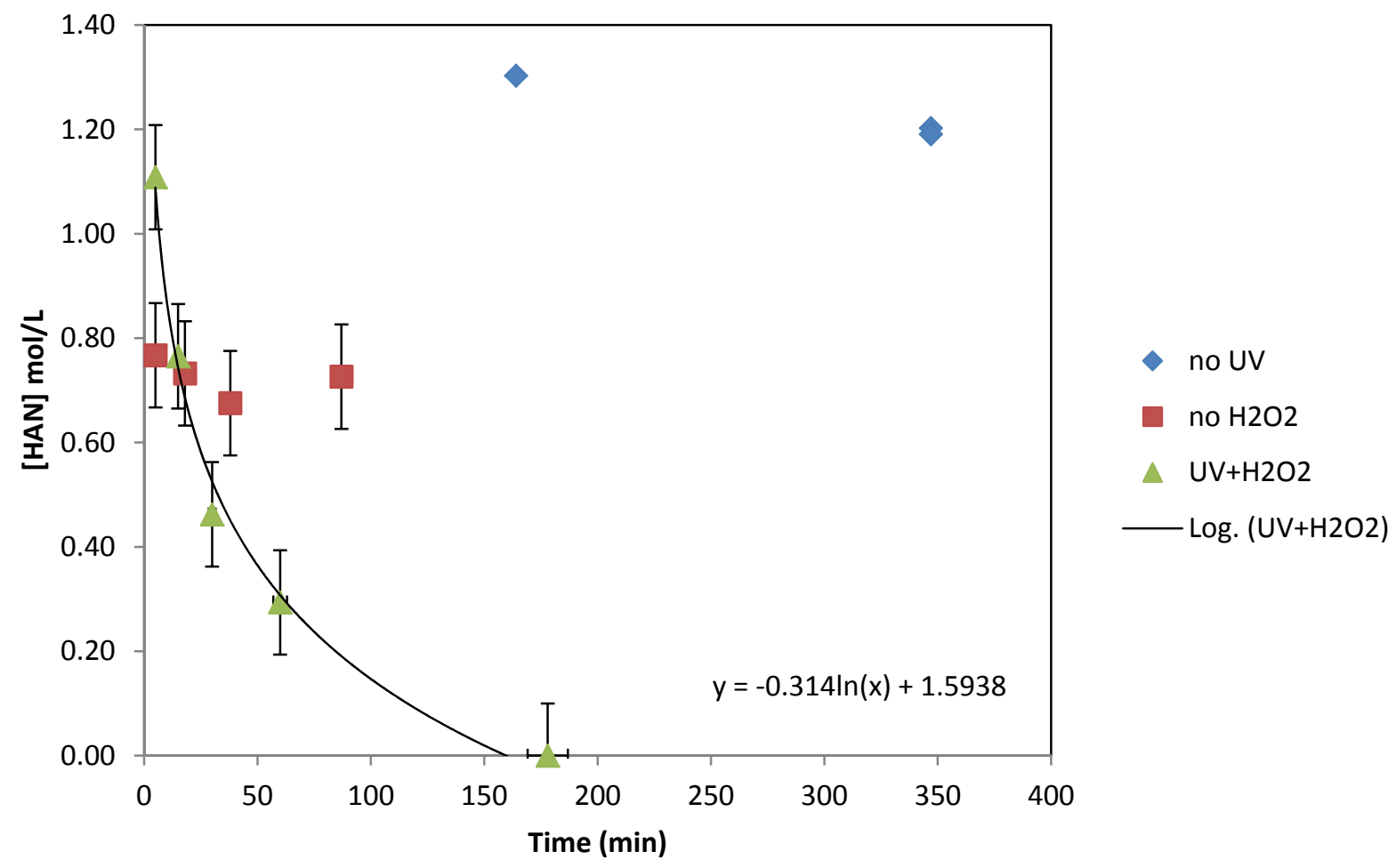

Figure 12. HAN concentration (mol/L) as a function of time (min) under $\mathrm{UV}$ and $\mathrm{H}_{2} \mathrm{O}_{2}$. 


\subsubsection{Reaction with Fe(III)}

In these tests, $\mathrm{FeCl}_{3}$ was added to $\mathrm{HAN}$ at room temperature $\left(21^{\circ} \mathrm{C}\right)$ as $\mathrm{Fe}(\mathrm{III})$ is expected to oxidize the HAN in a similar way to other metals. The resulting initial concentration were $0.4 \mathrm{M}$ HAN and $0.3 \mathrm{M} \mathrm{Fe}(\mathrm{III})$. After allowing the reaction to progress, $100 \mu \mathrm{L}$ was pipetted into an analysis mixture of $\mathrm{HNO}_{2}$ and $\mathrm{HNO}_{3}$. After allowing the decomposition of $\mathrm{HNO}_{2}$ by residual $\mathrm{HAN}$, the mixture was analyzed using UV spectrophotometry. Because the Fe(III) itself increased the background at low wavelengths, only the $\mathrm{HNO}_{2}$ peaks at 371 and $386 \mathrm{~nm}$ were used in the analysis of HAN destruction, the former proving more reliable for analysis. The tests with Fe(III) were done in DI and in the presence of $1 \mathrm{M}$ $\mathrm{HNO}_{3}$ and results are show in Figure 13 for the $371 \mathrm{~nm}$ absorbance.

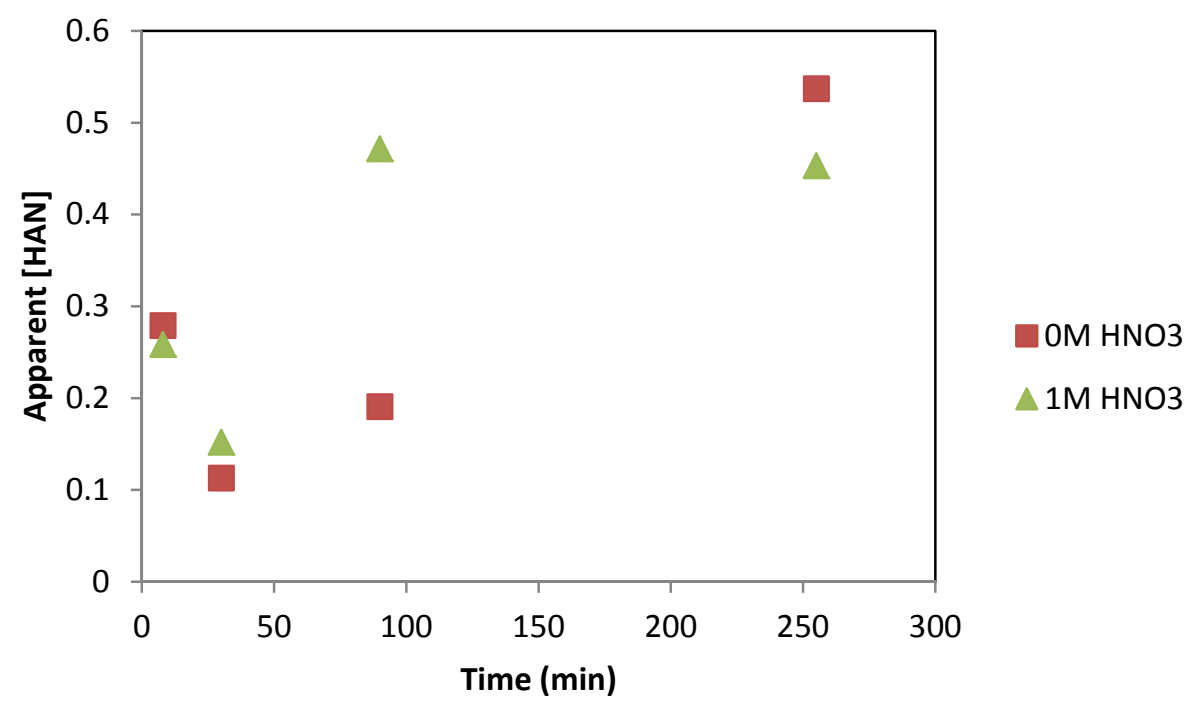

Figure 13. Apparent [HAN] $(\mathrm{mol} / \mathrm{L})$ as a function of time, from monitoring of the $\mathrm{HNO}_{2}$ absorption at $371 \mathrm{~nm}$.

The results from the contact with Fe(III) repeated show an initial decomposition of HAN through an increase in $\mathrm{HNO}_{2}$ concentration, but over time, the $\mathrm{HNO}_{2}$ itself is decomposed. Although anomalously high levels of HAN are calculated by difference at longer times, 90 minutes and longer, there is no mechanism for HAN to be reformed from the constituents in solution. Rather, the reaction

$$
\mathrm{Fe}^{2+}+\mathrm{HNO}_{2}+\mathrm{H}^{+} \rightarrow \mathrm{Fe}^{3+}+\mathrm{NO}+\mathrm{H}_{2} \mathrm{O}
$$

is likely occurring, breaking down residual $\mathrm{HNO}_{2}$. Thus, although $\mathrm{Fe}(\mathrm{III})$ appears to remove HAN, the mechanism is more complex and the results more ambiguous than with the combined thermal and nitric acid, or UV treatments. 


\section{CONCLUSIONS}

Although radiolysis has shown rapid degradation of HAN, if it is to be used in solutions that have lower concentrations of $\mathrm{Pu}-238$, there are a number of ways to successfully eliminate the HAN from solution. Safe operation when working with HAN appears to be with less than $2 \mathrm{M} \mathrm{HNO}_{3}$ at temperatures up to $60^{\circ} \mathrm{C}$. This appears to be in agreement with the stability index calculation proposed by SRNL up to $2 \mathrm{M}$, as shown in Figure 2, giving results of the calculation of the maximum reagent temperature for safe handling of $\mathrm{HAN}$ in $\mathrm{HNO}_{3}$.

If immediate destruction is desired, this can be achieved in a controlled manner by heating of the HAN solution to $75^{\circ} \mathrm{C}$ mixed with concentrations of $\mathrm{HNO}_{3}$ of at least $3 \mathrm{M}$. Dropwise addition of HAN into heated $\mathrm{HNO}_{3}$ allows control of the rate of reaction, imposing a limitation based on the concentration of reagents, although this method may be too complex for handling large volumes of spent HAN. UV photolysis of HAN in the presence of $\mathrm{H}_{2} \mathrm{O}_{2}$ also appears to be a viable method for HAN removal, and can be controlled by restricting the power of the UV lamp or the amount of $\mathrm{H}_{2} \mathrm{O}_{2}$ added as a reagent. Control of the UV intensity may be more manageable than the metering of reagents suggested by the other methods. Use of an additional metal, such as Fe(III), likely will complicate the redox chemistry of the solution and so is not recommend for HAN removal from already-metal laden solutions. 



\section{REFERENCES}

1. USCSHIB, The Explosion at Concept Sciences: Hazards of Hydroxylamine. 2002, US Chemical Safety and Hazard Investigation Board: Washington DC1999-13-C-PA.

2. NRIFD. Establishment of a Dangerous Material Determination Test Method with a View to Its Institutionalization as an International Standard. 2012 6/8/2012]; Available from: http://www.fri.go.jp/cgibin/hp/index_e.cgi?Page=hpd_view\&ac1=ERR1\&ac2=21\&ac3=13[6/8/2012.

3. W.S. Durant, L.W. Gray, R.M. Wallace, and W.W.F. Yau, Explosions and Other Uncontrolled Chemical Reactions at Non-Reactor Nuclear Facilities of the Savannah River Plant. 1988, Argonne National Laboratory. DP-MS-88-15.

4. D.G. Harlow, R.E. Felt, S. Agnew, G.S. Barney, J.M. McKibben, R. Garber, and M. Lewis, Technical Report on Hydroxylamine Nitrate. 1998, US Department of Energy. US DOE/EH-555.

5. S. Raman, R.W. Ashcraft, M. Vial, and M.L. Klasky, "Oxidation of Hydroxylamine by Nitrous and Nitric Acids. Model Development from First Principle Scrf Calculations". J Phys Chem A, 2005. 109: p. 8526-8536.

6. J.C. Mailen and O.K. Tallent, Solvent Degradation and Cleanup: A Survey and Recent Ornl Studies, in International Topical Meeting on Fuel Reprocessing and Waste Management. 1984: Jackson Hole, WY.

7. P. Patigny, J. Regnier, P. Miquel, and D. Taillard, Utilisation of Hydroxlamine Nitrate for the Final Concentration and Purification of Plutonium in the Irradiated Fuel Processing Factory at La Hague, in International Solvent Extraction Conference. 1974, Commissariat a l'Energie Atomique: Lyon, France.

8. U. Nations, Recommendations on the Transport of Dangerous Goods, in Manual of Tests and Criteria. 2003, United Nations: New York and Geneva.

9. R.J. Gowland and G. Stedman, "Kinetic and Product Studies on the Decomposition of Hydroxylamine in Nitric Acid". Journal of Inorganic and Nuclear Chemistry, 1981. 43(11): p. 2859-2862.

10. M.R. Bennett, G.M. Brown, L. Maya, and F.A. Posey, "Oxidation of Hydroxylamine by Nitrous and Nitric Acids". Inorg. Chem., 1982. 21: p. 2461-2468.

11. L.O. Cisneros, X. Wu, W.J. Rogers, M.S. Mannan, J. Park, and S.W. North, "Decompositoin Products of 50 Mass\% Hydroxylamine/Water under Runaway Reaction Conditions". Trans IChemE, 2003. 81(B).

12. L. Liu, M. Papadaki, E. Pontiki, P. Stathi, W.J. Rogers, and M.S. Mannan, "Isothermal Decomposition of Hydroxylamine and Hydroxylamine Nitrate in Aqueous Solutions in the Temperature Range 80-160C". J. Hazard. Mater., 2009. 165, p. 573-578.

13. M. Lefort and X. Tarrago, "Importance Et Role Du Radical $\mathrm{NH}_{2}$ Dans La Decomposition De "Lhydorxylamine Par Les Rayonnements Ionisants En Solutions Aqueuse". Journal of Inorganic and Nuclear Chemistry, 1961. 16: p. 169-186.

14. R.T. Bailey, F.R. Cruickshank, D. Pugh, and I.J.M. Weir, "The Thermal-Diffusivity and ThermalConductivity Coefficient of Methanol Vapor". Chemical Physics Letters, 1987. 134(4): p. 311315.

15. T. Adamopoulou, M.I. Papadaki, M. Kounalakis, V. Carreto, A. Pineda, and M.S. Mannan, "Use of Isoperibolic Calorimetry for the Study of the Effect of Water Concentration, Temperature and Reactor Venting on the Rate of Hydroxylamine Thermal Decomposition". Journal of Loss Prevention in the Process Industries, 2012.

16. G.S. Barney and P.B. Duval, "Model for Predicting Hydroxylamine Nitrate Stability in Plutonium Process Solutions". J. Loss Prevention in the Process Industries, 2011. 24: p. 76-84. 
17. Y. Iwata and H. Koseki, "Decomposition of Hydroxylamine/Water Solution with Added Iron Ion". Journal of Hazardous Materials, 2003. 104: p. 39-49.

18. Y. Iwata, H. Koseki, and F. Hosoya, "Study on Decomposition of Hydroxylamine/Water Solution". Journal of Loss Prevention in the Process Industries, 2003. 16: p. 41-53.

19. L.O. Cisneros, W.J. Rogers, and M.S. Mannan, "Adiabatic Calorimetric Decomposition Studies of 50 Wt.\% Hydroxylamine/Water". J. Hazard. Mater., 2001. A82: p. 13-24.

20. L. Liu, The Safe Storage of Autocatalytic Reactive Chemicals, in Chemical Engineering. 2009, Texas A\&M.

21. P.C.J. Moews and L.F. Audreith, "The Autoxidation of Hydroxylamine". J Inorg Nucl Chem, 1959. 11: p. 242-246.

22. L.O. Cisneros, W.J. Rogers, and M.S. Mannan, "Comparison of the Thermal Decomposition Behavior for Members of the Hydroxylamine Family". Thermochim. Acta, 2004. 313: p. 177-183.

23. L. Liu, C. Wei, Y. Guoa, W.J. Rogers, and M.S. Mannan, "Hydroxylamine Nitrate Self-Catalytic Kinetics Study with Adiabatic Calorimetry". Journal of Hazardous Materials, 2009. 162: p. 1217-1222.

24. A.G. Merzhanov and V.G. Abramov, "Thermal Explosion of Explosives and Propellants. A Review". Propellants and Explosives, 1981. 6: p. 130-148.

25. C. Wei, S.R. Saraf, W.J. Rogers, and M.S. Mannan, "Thermal Runaway Reaction Hazards and Mechanisms of Hydroxylamine with Acid/Base Contaminants". Thermochimica Acta, 2004. 421: p. 1-9.

26. R.J. Lewis, Sax's Dangerous Properties of Industrial Materials. 9th ed. 1996: Van Nostrand Reinhold.

27. S. Balasubramanian, J.D. Allen, A. Kanitkar, and D. Boldor, "Oil Extraction from Scenedesmus Obliquus Using a Continuous Microwave System - Design, Optimization, and Quality Characterization". Bioresource Technology, 2011. 102(3): p. 3396-3403.

28. J.M. McKibben, D.F. Chostner, and E.G. Orebaugh, Plutonium-Uranium Separation in the Purex Process Using Mixtures of Hydroxylamine Nitrate and Ferrous Sulfamate. 1983, Savannah River Laboratory: Aiken, SC. DP-1656.

29. N. Karpel Vel Leitner, P. Berger, G. Dutois, and B. Legube, "Removal of Hydroxylamine by Processes Generating Oh• Radicals in Aqueous Solution". Journal of Photochemistry and Photobiology A:Chemistry, 1999. 129: p. 105-110.

30. J.R. Smith, Radiolysis Gases from Nitric Acid Solutions Containing HSA and HAN (U) 1994, Savannah River Laboratory: Aiken, SCWSRC-TR-94-0525.

31. A. Chesné, Solvent Extraction in Nuclear Fuel Reprocessing, in International Solvent Extraction Conference. 1980, Commissariat à l'Energie Atomique: Liege, Belgium.

32. D.G. Karraker, Relative Reaction Rates of Sufamic Acid and Hydroxylamine with Nitric Acid. 1986, Savannah River Laboratory. DPST-86-694.

33. L. Venault, P. Moisy, P. Blanc, and C. Madic, "Kinetics of Hydrazinium Nitrate Decomposition in Nitric Acid Solutions under the Effect of Power Ultrasound". Ultrasonics Sonochemistry, 2001. 8: p. 359-366.

34. M. Strous. Analysis of N-Compounds. 200423 September 2004 6/5/2012]; Available from: http://www.microbiology/science.ru/ml/tech/n-compounds.

35. J. Stutz, E.S. Kim, U. Platt, P. Bruno, C. Perrino, and A. Febo, "Uv-Visible Absorption Cross Sections of Nitrous Acid". J Geophysical Research, 2000. 105(D11): p. 14,585-14,592.

36. Y. Zuo and Y. Deng, "The near-Uv Absorption Constants for Nitrite Ion in Aqueous Solution". Chemosphere, 1998. 36(1): p. 181-188. 


\section{APPENDIX A. LAB BOOKS USED}





\section{APPENDIX A. LAB BOOKS USED}

1. Dec. $18 / 14$ - preparation of hydroxylamine sulfate $+\mathrm{Ba}\left(\mathrm{NO}_{3}\right)_{2}$ to make $\mathrm{HAN}$ (p.120 lab book, B004772)

2. Dec. $19 / 14$ - measurement of $\mathrm{HAN}$ by $\mathrm{HNO}_{2}$ in UV-Vis (p. 121 lab book, B004772)

3. Jan. 22-27/15 - study with different concentrations $\mathrm{HNO}_{3}$ (2 mM to $849 \mathrm{mM}$ ), $62 \mathrm{mM}$ HAN (p. 123-125 in lab book, B004772)

4. Jan 29-0.3 M HAN (0.02 to 8 M HNO3), p. 126-7 in lab book B004772

5. Heating test of $\mathrm{HAN}\left(62.5 \mathrm{mM}\right.$ in $\left.0.08 \mathrm{M} \mathrm{HNO}_{3}\right)$, p.128

6. Feb 6-7, 2015, Boiling in $2 \mathrm{M} \mathrm{HNO}_{3}$, adding of aliquots of $\mathrm{HAN}$ to $\mathrm{HNO}_{3}$, p. 129-130

7. March 23 and 24, reactions with Fe(III), p. 1-4 of lab bookH00071

8. March 27\&30, reactions with OH radical, p. 4-6 of lab book H00071. 